\title{
Potential Output and Recessions: Are We Fooling Ourselves?
}

Martin, Robert, Teyanna Munyan, and Beth Anne Wilson

Please cite paper as:

Martin, Robert, Teyanna Munyan, and Beth Anne Wilson

(2015). Potential Output and Recessions: Are We Fooling Ourselves?

International Finance Discussion Papers 1145.

http://dx.doi.org/10.17016/IFDP.2015.1145

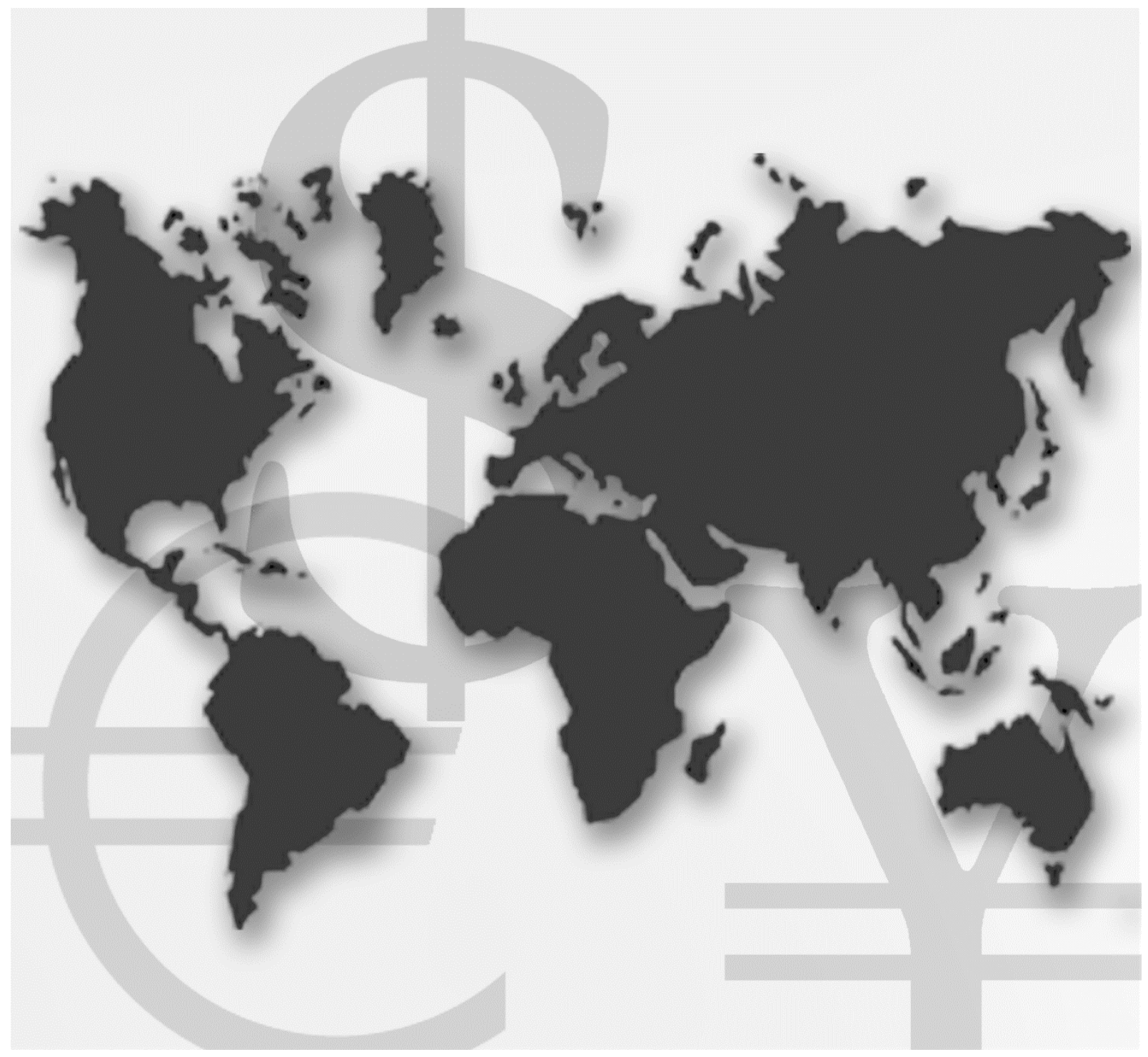

\section{International Finance Discussion Papers}

Board of Governors of the Federal Reserve System

Number 1145

September 2015 


\title{
Board of Governors of the Federal Reserve System \\ International Finance Discussion Papers
}

Number 1145

September 2015

\section{Potential Output and Recessions: Are We Fooling Ourselves?}

\author{
Robert Martin \\ Teyanna Munyan \\ Beth Anne Wilson
}

NOTE: International Finance Discussion Papers are preliminary materials circulated to stimulate discussion and critical comment. References to International Finance Discussion Papers (other than an acknowledgment that the writer has had access to unpublished material) should be cleared with the author or authors. Recent IFDPs are available on the Web at www.federalreserve.gov/pubs/ifdp/. This paper can be downloaded without charge from the Social Science Research Network electronic library at www.ssrn.com. 



\title{
Potential Output and Recessions: Are We Fooling Ourselves?
}

\author{
Robert Martin \\ Teyanna Munyan \\ Beth Anne Wilson*
}

\begin{abstract}
This paper studies the impact of recessions on the longer-run level of output using data on 23 advanced economies over the past 40 years. We find that severe recessions have a sustained and sizable negative impact on the level of output. This sustained decline in output raises questions about the underlying properties of output and how we model trend output or potential around recessions. We find little support for the view that output rises faster than trend immediately following recessions to close the output gap. Indeed, we find little evidence that growth is faster following recessions than before; if anything post-trough growth is slower. Instead, we find that output gaps close importantly through downward revisions to potential output rather than through rapid post-recession growth. The revisions are made slowly (over years) - a process that leads to an initial underestimation of the effect of recessions on potential output and a corresponding under-prediction of inflation.
\end{abstract}

Keywords: business fluctuations, cycles, general macro, international business cycles JEL classifications: E32, E20, F44

${ }^{*}$ Robert Martin is Director, U.S. Economist, Barclays Investment Bank, Teyanna Munyan is a graduate student at Vanderbilt University, and Beth Anne Wilson (bawilson@frb.gov) is Senior Associate Director in the Division of International Finance, Board of Governors of the Federal Reserve System, Washington, D.C. 20551 U.S.A. We thank Gregory Howard for contributions, Andrew Brooks and Caitlin Hegarty for excellent assistance, Andrea Raffo for sharing his dataset, and Matteo Iacoviello, Troy Davig, Olivier Blanchard, and Stanley Fischer and participants at workshops within the Federal Reserve System, the IMF, and the Bank of England for their comments. The views in this paper are solely the responsibility of the authors and should not be interpreted as reflecting the views of the Board of Governors of the Federal Reserve System or of any other person associated with the Federal Reserve System 



\section{Introduction}

The economic collapse in the wake of the global financial crisis and the weaker-thanexpected recovery that followed in many countries have led to questions about the effect of such events on economic potential. There are numerous reasons why recessions, especially severe ones, might affect potential output: Falling investment can depress the level of technical change embodied in the capital stock. Firms may have less incentive to invest in innovation. Unemployed workers may lose job skills and/or leave the labor force. Structural change may force workers to acquire new skills and there may be less learning-by-doing or other types of informal innovation. Counterbalancing this, recessions could produce a "cleansing effect," increasing the productivity of the surviving firms and workers. And, of course, the recession itself could have been driven by a shock to the level of productivity.

A number of recent studies have found evidence that banking and financial crises have a negative impact on potential output or its components, suppressing productivity, labor input, and capital deepening (Oulton and Sebastiá-Barriel (2013), Furceri and Mourougane (2012), Abiad et. al. (2009)). Other studies have calculated notable effects of the Great Recession on potential output for specific countries. ${ }^{1}$ More generally, Haltmaier (2012) has examined the impact of recessions on measures of trend output for a panel of countries. Haltimaier finds trend growth is significantly slower in the period two to four years after a cyclical peak than in the two years prior to the peak.

Most of these studies regress time-series measures of actual or trend real GDP growth on dummies indicating periods of financial crisis to estimate the crisis impact on growth, period by period. The magnitude of total output loss is then calculated as the deviation between actual or potential output and some counterfactual measure extrapolated using the estimated impact of crises on growth rates. These growth exercises imply that the level of trend output falls during severe recessions and does not easily recover.

In this paper, we begin by examining the impact of recessions more generally on the level of GDP compared to pre-recession trend. We use quarterly data on real GDP over the past 40 years for 23 advanced economies, resulting in observations on 150 recessions. We take care to calculate trend output such that it is not influenced by outcomes following the cyclical peak i.e. we do not allow the trend to be revised down based on ex-post recovery experiences as is

\footnotetext{
${ }^{1}$ See, for example, Gaggl and Janger (2009) regarding Austria and the European Commission (2009) for selected EU countries.
} 
done, for example, in standard Hodrick-Prescott filtering techniques. We find that, following severe recessions, including those associated with banking and financial crises, output remains below pre-recession trend for an extended period. Even for the average recession there may be small permanent effects on the level of output relative to pre-recession trend. Our findings are supported by related work estimating the impact of financial crises on actual output which suggests sustained deviations from pre-crisis peaks. ${ }^{2}$ We provide evidence that the sustained output loss following recessions is associated with relative declines across most output components, importantly a reduction in labor input linked to declines in employment and laborforce participation and a hit to the level of investment.

This sustained decline in output raises questions about the underlying properties of output and how we model trend. ${ }^{3}$ We find little support for standard models which have output rising faster than trend immediately following recessions in order to close the output gap. Indeed, using basic statistical tests, we find some evidence that growth rates are faster before than immediately after recessions, even excluding years immediately before the peak which could be considered "bubbles." Instead, we show that downward revisions to potential output play an important role in closing the output gap. Adjustment is not immediate, however. OECD forecasts of potential output and the output gap indicate that responding to recessions is a slow process in which policymakers initially underestimate of the impact of recessions on potential output and correspondingly under-predict inflation.

Following this introduction, section II of the paper looks at the impact of recessions on medium- to long-run growth. Section III examines the components of GDP to understand what does not recover. Section IV focuses on the implications of these results for forecasting. Section $\mathrm{V}$ concludes.

\section{Recessions and Medium- to Long-run Growth}

As discussed above, one implication of recent research on the impact of financial crises on output is that GDP remains depressed from pre-crises levels for a substantial period of time, implying a persistent gap between the pre-crisis trend and the post-crisis level of output.

Figure 1, showing the level of real GDP growth for selected advanced economies in the past

\footnotetext{
${ }^{2}$ For example, Cerra and Saxena (2008), Cerra et al. (2013), Terrones et al. (2009), Reinhart and Reinhart (2010), and Howard et al. (2011).

${ }^{3}$ The issue of the time-varying nature of long-run and short-run potential output has been discussed in Basu and Fernald (2009) among others.
} 
decade or so, illustrates this clearly. Real GDP for the United States, as well that for Canada, the euro area, and the United Kingdom, fell sharply during the Great Recession and has made little progress toward closing the gap relative to pre-recession trend. ${ }^{4}$ This economic behavior stands in contrast to how many economists and forecasters model the recovery path of output. In general, following a negative shock, GDP is expected to return relatively quickly to pre-crisis trend (figure 2), implying faster-than-average output growth immediately following recessions. If the recent behavior of GDP in these advanced economies is typical of the behavior of output following severe recessions, then either permanent or sustained gaps open up between actual and trend output, or such recessions have negative and sustained impacts on trend as well as actual output.

These questions about the behavior of GDP around recessions are not new. In the 1970s and 1980s, a large literature developed on testing the stability of GDP around trends. Two camps evolved. Simply put, the first camp, spearheaded by Nelson and Plosser (1982), believed that all innovations to GDP were permanent - that is, that GDP was essentially a random walk. The other camp viewed GDP as stable around a fixed trend, as argued in Rudebusch (1993) and Ben-David and Papell (1995). In this case, GDP was essentially trend-stationary and deviations in GDP from trend would result in above or below average growth for a period as GDP climbed back towards trend. In general, policy makers have chosen to view output as trend stationary and typically model it as such. This view was made easier by the relative stability of GDP during the Great Moderation. Now, however, it may be useful to recall other work, notably by Diebold and Rudebusch (1989), that suggests that the rate of convergence of output to trend is very slow potentially decades - raising questions about the wisdom of treating output as returning to trend within the two- to five-year range commonly used by policy-making institutions and businesses for their forecasts.

To be trend stationary around turning points, GDP growth must expand sufficiently fast following a recession relative to its pre-recession rate to compensate for the decline in output. In the remainder of this section, we use several methods to assess whether in our cross-country sample of recessions, GDP growth accelerates after recessions, returning output to pre-recession trend, or trend output is adjusted to close the gap - in other words, do recessions negatively impact trend output.

\footnotetext{
${ }^{4}$ Here we calculate trend output by applying an HP filter to real GDP data over the entire sample for each country.
} 
To do this, we face both a conceptual and a practical challenge. To study cyclical behavior of the economy, data are typically detrended using Hodrick-Prescott, Kalman, or other frequency-based filters (e.g. the band-pass filter). By necessity, these techniques use all available data to infer the underlying trend and the statistical properties of the filters improve as more data become available. As a result, the estimated trend at any point in time changes as the data evolve.

More critically, and of great importance to our work, these detrending tools cannot accommodate a permanent deviation from trend. Any permanent step up or step down in the level of GDP say, for example, after a recession, will be accommodated by the filter as a change in growth—both before and after the recession. In practice, this feature implies that following recessions, especially those with large declines in output, estimates of trend growth immediately surrounding the recession will evolve. Eventually, the filter will show a large positive difference between actual GDP and estimated trend before the recession and a large negative gap in its immediate aftermath.

For this reason, in our main results we choose to use a simple exponential trend, estimated recession-by-recession using nearby data, which can accommodate such long-lasting deviations. Even with this methodology, determining the appropriate pre-recession trend is somewhat tricky to the extent that banking and financial crises are associated with bubbles or positive deviations from trend prior to the crisis. To avoid including the bubble in our trend, we calculate the four-year average growth rate for each country, two years prior to the peak, thus excluding what may be a rapid period of growth before the crisis. (The results are similar using average growth calculated over different pre-peak intervals.)

For our comparisons, we use an unbalanced panel of quarterly GDP data for 23 advanced economies (AEs) from 1970 (or whenever we begin to have quarterly GDP data) to present. Most data are from national sources, and a full list of countries can be found in appendix A. For comparability across countries, we use a standard recession dating methodology - the BryBoschen procedure for quarterly data (or BBQ method) as described by Harding and Pagan (2002). ${ }^{5}$ We the check the robustness of our results using other recession-dating methodologies in the literature. Using the BBQ definition of recession, our sample contains 150 recessions. If

\footnotetext{
${ }^{5}$ The BBQ method identifies cyclical peaks and troughs as local maxima in the two quarters preceding and the two quarters following. It then eliminates maxima that do not alternate between peaks and troughs or do not have a long enough time span, in this case two quarters from a peak to trough and four quarters from a trough to peak. Once these criteria are met, recessions are defined as the time between a peak and a trough.
} 
the Great Recession is excluded, the sample is reduced to 117 recession episodes. (See appendix $\mathrm{B}$ for data range for each country in our sample.) Unless otherwise indicated, we choose to exclude the Great Recession from our calculations. This allows us to look at the behavior of output well after the recession trough. However, our results are robust to including these observations.

Having calculated a pre-recession trend, we examine GDP as a percentage of this trend for each recession in our sample prior to the Great Recession and then calculate the crosscountry average to determine the mean deviation in output from pre-crisis trend around recessions (figure 3). We also make this calculation for three specific types of downturns recessions that are particularly mild (those in the lower quartile for recession length and depth), severe recessions (those where the length and output loss from peak to trough fall in the upper quartile), and banking and financial recessions (as defined by Laeven and Valencia (2012)). 67 Average GDP never recovers to trend, even for short and shallow recessions. Deep and long recessions lead to a sustained loss from pre-recession trend of about 10 percent after 8 years. ${ }^{8}$ Recessions associated with banking and financial crises also result in sustained losses to output greater than the average recession, but less so than deep and long recessions more broadly. This is not because the recovery is faster in banking and financial crises but because only a third of the banking and financial recessions in our sample qualify as severe. ${ }^{9}$ So while the group of banking and financial recessions has a higher percentage of severe recessions (30

\footnotetext{
${ }^{6}$ We define recession length as the number of quarters from pre-recession peak to recession trough and recession depth as the decline in the level of real GDP from pre-recession peak to recession trough.

${ }^{7}$ There is some but not complete overlap between the severe recessions and the banking and financial recessions. The banking and financial recessions in our sample are the following countries and trough dates: Finland 1993Q1, Greece 1983Q2, Iceland 1983Q2, Italy 1982Q4, Japan 1998Q2, Norway 1993Q1, New Zealand 1986Q1, Portugal 1984Q2, Sweden 1992Q4, Spain 1979Q1. The deep and long recessions include the Finland 1993Q1, Greece 1983Q2, and Sweden 1992Q4 recessions from the banking and financial group, as well as Australia 1983Q2, Canada 1982Q4, Denmark 1975Q4, Greece 1987Q2, Iceland 1992Q4, Luxembourg 1975Q3, New Zealand 1978Q1, Portugal 1975Q2, Switzerland 1976Q1, UK 1975Q3, and UK 1981Q1.

${ }^{8}$ See also Haltmaier (2012) and Oulton and Sebastiá-Barriel (2013) which find similar long-run effects on output from deep recessions.

${ }^{9}$ Interestingly, given the recent discussion of the severity of banking and financial crises, we find that the recessions in our small sample of pre-GFC banking and financial crises do not all have severe spillovers into the economy. Even though three are categorized as severe (see footnote 7) and three others almost count as severe (Japan 1998Q2, NZ 19861, and Portugal 1984Q2), of the 10 pre-GFC crises three almost count as mild (Italy 1982Q4, Norway 1993Q1, and Spain 1979Q1). Both the Norway and Spain banking crises are preceded by financial liberalization which created a credit boom and the government acted quickly to deal with the failing banks (see Steigum, 2010 and Ingves et al., 2009). In the case of Norway the boom was shorter than for Sweden and Finland, which ended up having a more severe recession at that time. In the case of Spain, the core large banking institutions were not seriously affected, only a subset of the smaller banks, somewhat mitigating the effect of the crisis on the economy.
} 
percent) than the whole sample (12 percent), it cannot be said that all banking and financial recessions are severe.

Although varying the specification of our recessions or the definition of pre-crisis trend can modify these loss estimates across recession categories, these exercises all suggest a sustained hit to output, especially from severe recessions. Not surprisingly, including the Great Recession observations strengthens the result.

Another way we test if GDP returns to its pre-crisis trend is by evaluating how average growth in the four years immediately after recessions differs from the pre-recession trend pace. We do this by constructing scatterplots showing the pre-recession trend growth and postrecession average growth rates for each recession. If the stylized fact is true that GDP growth bounces back quickly after a recession, then we should expect to see the observations concentrated above the 45 degree line. Figure 4 reveals several interesting features of recession recoveries. First, the broad dispersion of the observations above and below the 45 degree line illustrates the diversity of recovery experiences in our sample. That said, it is clear that most recoveries are not characterized by faster-than-average growth. A majority of the observations fall near or below the 45 degree line indicating about average or below average growth following recessions. This remains true if the four outliers to the extreme right are removed, if we look at only the first year of a recovery, and if we take a longer-run perspective and construct scatterplots of average growth over the total sample for each country and average pace of growth by country four years after a recession trough. All of these variations indicate that for most recessions there is no quick return to pre-recession trend levels.

Table 1 confirms this result, showing that for average, severe, mild, and banking and financial recessions the average growth rate in the four years after the recession trough is actually below that of the four years ending two years prior to the pre-recession peak. ${ }^{10}$ Indeed, a simple correlation regression of post-recession growth on pre-recession average finds a coefficient of $0.7 .{ }^{11}$ That is, on average, growth after the recession is only about 70 percent as fast as pre-recession growth. To recover the output lost during a recession, the coefficient would need to be considerably above 1 . As an example, to make up the average decline in output in our sample from pre-recession peak to recession trough of roughly 3 percent over a period of four

\footnotetext{
10 These results remain robust to changing both the pre-and post-recession definition of trend to include periods of longer or shorter duration and to including the Great Recession. Moreover, building on our work, Blanchard, Cerutti, and Summers (2015) confirms this result both for a similar sample of countries and in cases where recessions are more linked to demand shocks or to supply shocks.

${ }^{11}$ With a standard error of 0.04 , the point estimate is a little more than 7 standard deviations from 1.
} 
years, the correlation coefficient would have to be 1.5, implying an annual growth rate of 5.4 percent for four years to make up the difference -- a growth rate that seems uncharacteristically strong for the advanced economies to sustain over a four-year period. Even to make up the gap over 10 years, the coefficient would need to be 1.2, implying an average annual growth rate of 4.3 percent. Since the global financial crisis, attention has been focused on the strength of recoveries from banking and financial crises. Given the average decline in output in our sample from such crises (4.5 percent) and the average pre-recession growth rate (3.6 percent), we would need to see growth averaging 5.9 percent at an annual rate to close the gap in four years and 4.5 percent to close the gap over a decade. The banking and financial crisis counties have fallen well short of this, with post-trough growth averaging only 3.1 percent at an annual rate.

There is a risk that our results for the advanced economies are simply picking up the slow decline in population growth across our sample period in most of these countries. This would tend to lower growth rates pre- and post-recession and reduce trend output growth, but may or may not have any effect on the difference between the two growth rates. To test for the impact of demographic changes, we redo our calculations using output normalized by working-age population. Figures 5 and 6 and table 2 show that controlling for population moderates the permanent impact of recessions but does not eliminate it, especially for severe and sustained output declines.

\section{A Simple Look at What Doesn't Recover}

Our work above suggests that the level of GDP, particularly after long and deep recessions, does not recover to its pre-crisis trend even years after the start of a recession, which raises the question: what is driving this sustained output loss? In general, even for the advanced economies, it is a challenge to get comparable quarterly time series data across countries to allow for a more granular look at post-recession behavior. One exception is a dataset developed by and detailed in Ohanian and Raffo (2014) which contains quarterly information on total hours, laborforce participation, employment, and average weekly hours for 15 OECD countries from 1960 to the 2013. ${ }^{12}$ With these data we can examine the broad supply-side components of output - total hours and output per hour - to see where the weakness in overall GDP lies following different types of recessions. Figure 7 shows, for the smaller sample used here, the average behavior of

\footnotetext{
12 The countries included are Australia, Austria, Canada, Finland, France, Germany, Ireland, Italy, Japan, Norway, Spain, Sweden, the United Kingdom, and the United States.
} 
the level of GDP as a percentage of pre-recession trend - divided into those that were particularly severe (in the top $25^{\text {th }}$ percentile of depth and duration), and all others. ${ }^{13}$ In all cases, the level of output fails to return to the pre-recession trend, with the gap being particularly sizable (about 7 percent) for severe recessions. Figures 8 and 9 break output down into total hours and output per hour for both sets of recessions. For typical recessions, the loss in output is a reflection of declines in both productivity and labor input. In contrast, for severe recessions, the sustained deviation in the level of output from trend is more than entirely accounted for by a loss in total hours - productivity actually increases relative to trend.

We next decompose total hours into labor force participation, the employment rate, and average weekly hours (figures 10 through 12). Interestingly, whereas the workweek returns and even exceeds its pre-recession trend relatively quickly, employment and labor force participation rates remain depressed - particularly after long and deep recessions. These results suggest the decline in output relative to pre-crisis trend, especially after severe recessions, is importantly concentrated in a reduction in the utilization of labor. For particularly bad recessions, the reduction in the employment and labor force participation rates is sustained even five years after the pre-recession peak. This sustained decline in labor-force participation around recessions and the Great Recession, in particular, has also been noted by Erceg and Levin (2014) and Stock and Watson (2012).

Cross-country measures of capital stock are difficult to obtain, so we proxy for the capital stock using the behavior of investment around recessions. Figure 15 indicates that the investment takes a hit during recessions, especially severe recessions, and remains well below pre-crisis trend. These results are supportive of other work found in the literature that finds a significant hit to capital deepening, labor input, and productivity following recessions and/or crises (Claessens et al (2008), Haltmaier (2012), and Oulton and Sebastiá-Barriel (2013)).

As another look at the behavior of output following recessions, we decompose real GDP into its demand-side components in figures 13 through 18. In particular, using a slightly different set of data covering 21 countries over 50 years, we examine the response of consumption, investment, government spending, exports, and imports around recessions. ${ }^{14}$ In

\footnotetext{
${ }^{13}$ We have chosen not to break down our analysis on the components of output by non-GFC banking and financial recessions because of the limited number of crises (5) that fall within the country/date range of the Ohanian and Raffo database.

${ }^{14}$ These countries include: Australia, Austria, Belgium, Canada, Denmark, Finland, France, Germany, Greece, Iceland, Italy, Japan, Luxembourg, the Netherlands, New Zealand, Norway, Portugal, Sweden, Switzerland, the United Kingdom, and the United States.
} 
this case, as before, we build individual trends for each component and present the median deviation of our sample from these trends. As was generally the case in the earlier decomposition, it appears that the negative impact of recessions is not concentrated in one component. All components take a hit but particularly for severe recessions for investment and imports.

\section{Implications}

In recessions, a gap opens up between the actual level of output and the pre-recession trend. This gap can be closed through above-trend growth, which is typical of economic forecasting models, or a lower level of potential output. One implication of the evidence above, showing that growth in the advanced economies is not faster immediately after recessions, is that at least some of the gap is closed by a reduction in potential or trend output. Interestingly, much of this downward revision appears to be ex-post rather than ex-ante. In particular, as economies recover and the lower level of actual output persists, potential output is typically revised down towards it.

This pattern of revision is especially true if potential is calculated using purely statistical techniques. For example, one reason output gaps appear to be transitory is likely that techniques to calculate trend are often two sided, bending in response to actual data. ${ }^{15}$ Figure 19 illustrates this phenomenon using U.S. real GDP data before and after the 2009 recession. As GDP slows and then declines during the recession, trend output, as calculated using an HP filter, gradually moderates toward actual output - reducing the negative gap between actual and trend data around the recession and increasing the positive gap prior to the start of the recession. Economists and policymakers using HP filtered data in 2007 would have a very different sense of their cyclical position in that year compared to their impression now for that same year. Moreover, it is clear that using this methodology, output is far from returning to the 2007 trend.

This pattern of revision also holds true if potential is calculated using more sophisticated “bottom up” approaches. Most policymaking institutions, especially more recently, use a growth accounting framework to build measures of potential output. To see how potential is adjusted around turning points using this methodology, we use data from the OECD economic outlook from 1989 to 2010 for 64 recessions in 23 different advanced economies. The OECD produces

\footnotetext{
${ }^{15}$ This issue is independent of the typical concern with two-sided filters, which is that they have difficulty estimating trends around endpoints of the data series.
} 
semi-annual projections of potential and actual output about two years forward. We construct a database of various vintages of the OECD’s potential estimates. Figures 20 and 21 show these vintages around recessions. What is interesting is that these data reveal a pattern of downward revisions to the level of potential around turning points. It is understandable that the projected level of potential growth over the next two years is lower around the trough than was estimated a year earlier. What is interesting is that, two years after the trough, the level of potential around the trough and over the preceding two years has again been lowered. This downward revision to growth in potential output is reflected in an upward revision to the output gap two years after the trough compared to expectations made near the recession trough.

The same pattern of systematic underestimation of the impact of recessions on potential and the subsequent downward revision of potential output holds true for a number of policymaking institutions during the Great Recession. For example, among other institutions, the U.S. Congressional Budget Office, the U.K. Treasury, and the European Commission all underestimated the extent of downward revision to potential related to the Great Recession. While it is tempting to attribute this to the impact of the financial crisis on growth, the discussion above suggests that this pattern is long standing.

Two implications of this analysis are that, one, policymakers should consider adjusting potential down more and more quickly following recessions. Two, the systematic over-

prediction of the output gap suggests an under-prediction of inflation during recoveries. ${ }^{16}$ This appears to be the case using vintages of OECD forecasts. As seen in figure 22, on average, inflation forecasts made three years after the trough are higher than those made before, at, or immediately following the trough. That said, the output gap is still negative, suggesting that recessions are putting downward pressure on inflation and we find some evidence that especially long recessions do put downward pressure on inflation in the advanced economies on average (figure 23) and during this latest cycle (figure 24).

\section{Conclusion}

We expand on earlier work in the literature that finds evidence that banking and financial crises are associated with persistent negative deviations in the level of GDP from pre-crisis trend. We extend this result and find that that this persistent deviation from trend exists after all

\footnotetext{
${ }^{16}$ See Bijapur (2012) for some evidence from OECD countries that inflationary pressures tend to be stronger after banking and financial crises which is attributed to impairment in productive potential.
} 
recessions, especially after severe recessions. The result is highly statistically significant and the results are robust to a variety of methods for recession dating and to very different tests of preand post-recession growth rates.

For GDP to return to its previous trend following a recession, GDP growth after the recession must rise faster than GDP growth prior to the recession and this increase must either be large or sustained. In other words, GDP must increase rapidly enough to overcome the drop in output associated with the trend-the deeper the recession, the faster this growth must be. We find no evidence that output growth quickens immediately following recessions - if anything growth is somewhat slower, indicating that the drop in GDP is quite permanent. This result raises questions about the underlying shocks that drive recessions. In particular, this loss of output may imply that demand shocks have permanent effects or that recessions are driven by long lasting supply or productivity shocks. In addition, we have focused on recessions, but positive shocks may lead to positive deviations from trend growth.

This sustained gap in actual output from pre-trend output levels contrasts with how economists and forecasters model growth and the path of output following recessions. We show that, in contrast to the typical assumption that output grows rapidly after recessions to close the output gap, the gap is also closed through revisions to potential output. Whether trend output is estimated by simple techniques such as HP or other band-pass filters, or through growth accounting frameworks, there is a consistent pattern of downward revisions to trend output surrounding recessions. This would suggest that much of the growth disappointment discussed during recoveries arises from unsubstantiated expectations of rapid growth following the recession. The downward revisions to potential output following recessions reflect the gradual acceptance that actual growth will not bring output back to its pre-recession trend level. We provide evidence that this pattern of revision leads to an initial overestimation of the size of the output gap and an underestimation of inflation immediately after recessions. As a profession, we may need to rethink how we adjust potential output and growth forecasts around recessions.

Both to support and understand the result, we also examine the drivers of "what doesn't recover" and find that the lower level of GDP following recessions reflects lower utilization of labor, particularly a decline in employment and labor force participation rates from earlier trend levels. Going forward, it will be important to examine these results in line with what we know from the micro labor literature about skill deterioration, hysteresis, and long-term unemployment. 
We must also understand what, if any, changes to the policy response to recessions should be made with this view of the post-recession behavior of the level of output. ${ }^{17}$ In particular, for policymakers, the results point to the sustained cost of recessions, especially deep and long ones, and may provide a rationale for strong and rapid policy responses to economic downturns rather than a wait and see approach.

${ }^{17}$ If recessions generate sustained declines in the level of output and possible declines in the pace of output growth, one implication would be greater stability leads to better long-run output performance, a result in sympathy with the findings of DeLong and Summers (1984). 


\section{Bibliography}

Abiad, Abdul G., Ravi Balakrishnan, Petya Koeva Brooks, Daniel Leigh, and Irina Tytell.

"What's the damage? Medium-term output dynamics after banking crises," in Financial Crises: Causes, Consequences, and Policy Responses, edited by Stijn Claessens, M. Ayhan Kose, Luc Laeven, and Fabián Valencia, 277-308, International Monetary Fund, 2014.

Basu, Susanto, and John G. Fernald. "What do we know (and not know) about potential output?" Federal Reserve Bank of St. Louis Review 91, July/August 2009 (2009): 187-213.

Ben-David, Dan and David H. Papell, "The great wars, the great crash, and steady state growth: Some new evidence about an old stylized fact,” Journal of Monetary Economics 36 (1995): 453475.

Bijapur, Mohan. "Do financial crises erode potential output? Evidence from OECD inflation responses." Economics letters 117, no. 3 (2012): 700-703.

Blanchard, Olivier, Eugenio Cerutti, and Lawrence Summers, "Inflation and Activity: Two Explorations, and their Monetary Policy Implications,” manuscript, May 2015.

Cerra, Valerie, and Sweta Chaman Saxena. "Growth Dynamics: The Myth of Economic Recovery." American Economic Review 98, no. 1 (2008): 439-457.

Cerra, Valerie, Ugo Panizza, and Sweta C. Saxena. "International evidence on recovery from recessions." Contemporary Economic Policy 31, no. 2 (2013): 424-439.

Claessens, Stijn, M. Ayhan Kose, and Marco E. Terrones. "What happens during recessions, crunches and busts?" Economic Policy 24, no. 60 (2009): 653-700.

DeLong, J. Bradford, and Lawrence H. Summers. "The changing cyclical variability of economic activity in the United States." In The American business cycle: Continuity and change, 679-734. University of Chicago Press, 1986.

Diebold, Francis X., and Glenn D. Rudebusch. "Long memory and persistence in aggregate output." Journal of Monetary Economics 24, no. 2 (1989): 189-209.

Erceg, Christopher J., and Andrew T. Levin. "Labor force participation and monetary policy in the wake of the Great Recession." Journal of Money, Credit and Banking 46, no. S2 (2014): 349.

European Commission. "Impact of the current economic and financial crisis on potential output." European Economy, Occasional Paper 49 (2009).

Furceri, Davide, and Annabelle Mourougane. "The effect of financial crises on potential output: new empirical evidence from OECD countries." Journal of Macroeconomics 34, no. 3 (2012): 822-832. 
Gaggl, Paul, and Jürgen Janger. "Will the Great Recession Lead to a Lasting Impact on Potential Output in Austria." Monetary Policy \& the Economy Q3 (2009): 26-52.

Haltmaier, Jane, “Do Recessions Affect Potential Output?” International Finance Discussion Papers, No. 1066, 2012.

Harding, Don, and Adrian Pagan. "Dissecting the cycle: a methodological investigation." Journal of Monetary Economics 49, no. 2 (2002): 365-381.

Howard, Greg, Robert F. Martin, and Beth Anne Wilson, “Are Recoveries from Banking and Financial Crises Really So Different,” International Finance Discussion Papers, No. 1037, 2011.

Ingves, Stefan, Göran Lind, Masaaki Shirakawa, Jaime Caruana, and Guillermo Ortiz Martínez. "Lessons Learned from Previous Banking Crises: Sweden, Japan, Spain, and Mexico."

Occasional Paper no. 79, Group of Thirty, 2009.

Laeven, Luc and Fabian Valencia "Systemic Banking Crises: A New Database,” IMF Working Paper, no. 08/224 (2008): 1-78.

Laeven, Luc and Fabian Valencia "Systemic Banking Crises: An Update,” IMF Working Paper, no. 12/163 (2012). 
Nelson, Charles R. and Charles I. Plosser, "Trends and random walks in macroeconomic time series: Some evidence and implications,” Journal of Monetary Economics 10, no. 2 (1982): 139162.

Ohanian, Lee E and Andrea Raffo, “Aggregate Hours Worked in OECD Countries: New Measurement and Implications for Business Cycles,” Journal of Monetary Economics 59, no. 1 (2012), updated 2014.

Oulton, Nicholas and María Sebastiá-Barriel, "Long and Short-Term Effects of the Financial Crisis on Labor Productivity, Capital, and Output,” Bank of England Working Paper, no. 47 (2013). (http://cep.lse.ac.uk/pubs/download/dp1185.pdf)

Reinhart, Carmen M. and Vincent R. Reinhart, 2010. “After the Fall,” Proceedings - Economic Policy Symposium - Jackson Hole, Federal Reserve Bank of Kansas City, pages 17-60.

Rudebusch, Glenn D. "The uncertain unit root in real GNP." The American Economic Review 83, no. 1 (1993): 264-272.

Steigum, Erling. "The Norwegian banking crisis in the 1990s: effects and lessons." BI Centre for Monetary Economics, Working Paper Series 5, no. 11 (2011).

Stock, James H., and Mark W. Watson. “Disentangling the Channels of the 2007-2009 Recession.” Brookings Papers on Economic Activity: Spring 2012. Brookings Institution Press, 2012.

Terrones, Marco E., Alasdair Scott, and Prakash Kannan. "From recession to recovery: How soon and how strong?" International Monetary Fund, World Economic Outlook, April (2009), Chapter 3. 
Table 1

\begin{tabular}{|c|c|c|c|}
\hline & 6-2 yrs prior to peak & $\begin{array}{l}\text { anced Economy GL } \\
\text { ercent Change, a.r. } \\
4 \text { yrs post-trough }\end{array}$ & p-value* \\
\hline All Recessions ex. GFC $(n=117)$ & 3.6 & 3.1 & $0.02^{*}$ \\
\hline Severe $(n=14)$ & 4.0 & 3.7 & 0.58 \\
\hline Mild $(n=15)$ & 3.0 & 2.2 & 0.15 \\
\hline All others $(n=88)$ & 3.7 & 3.1 & $0.04^{*}$ \\
\hline Note: Banking \& Financial $(n=10)$ & 3.6 & 3.3 & 0.72 \\
\hline
\end{tabular}

*Significant at the 95 percent level.

Table 2

\begin{tabular}{|c|c|c|c|}
\hline & $6-2$ yrs prior to peak & $\begin{array}{c}\text { nced Economy GDP } \\
\text { Percent Change, a.r. } \\
4 \text { yrs post-trough }\end{array}$ & p-value* \\
\hline All Recessions ex. GFC ( $n=117)$ & 2.9 & 2.3 & $0.02^{*}$ \\
\hline Long \& Deep (n=14) & 3.2 & 2.8 & 0.59 \\
\hline Short \& Shallow $(n=15)$ & 2.2 & 1.5 & 0.15 \\
\hline All others $(n=88)$ & 2.9 & 2.4 & $0.05^{*}$ \\
\hline Note: Banking \& Financial $(n=10)$ & 2.8 & 2.7 & 0.88 \\
\hline
\end{tabular}

*significant at the 95 percent level 


\section{Figure 1}

\section{U.S. Real GDP}

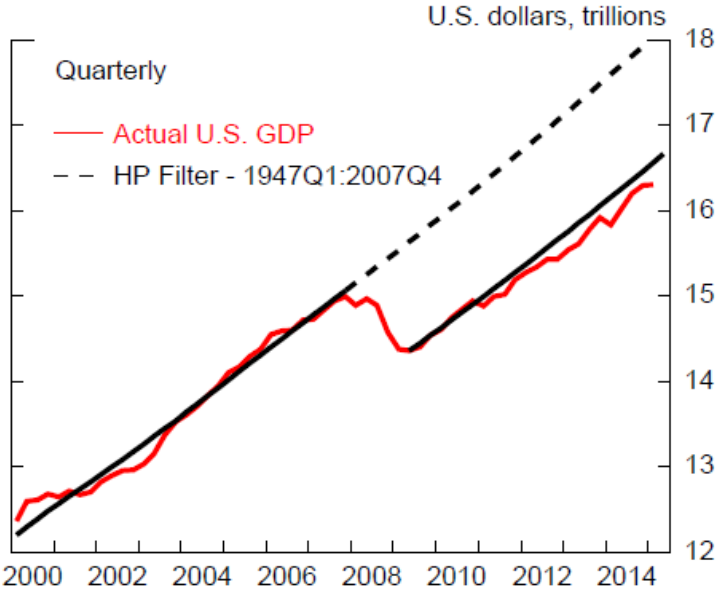

\section{Euro-Area Real GDP}

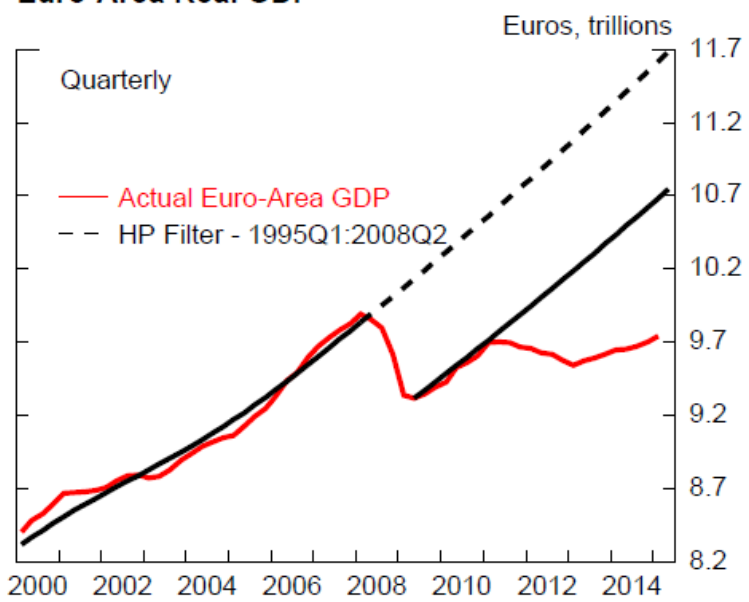

Figure 2. U.S. Real GDP

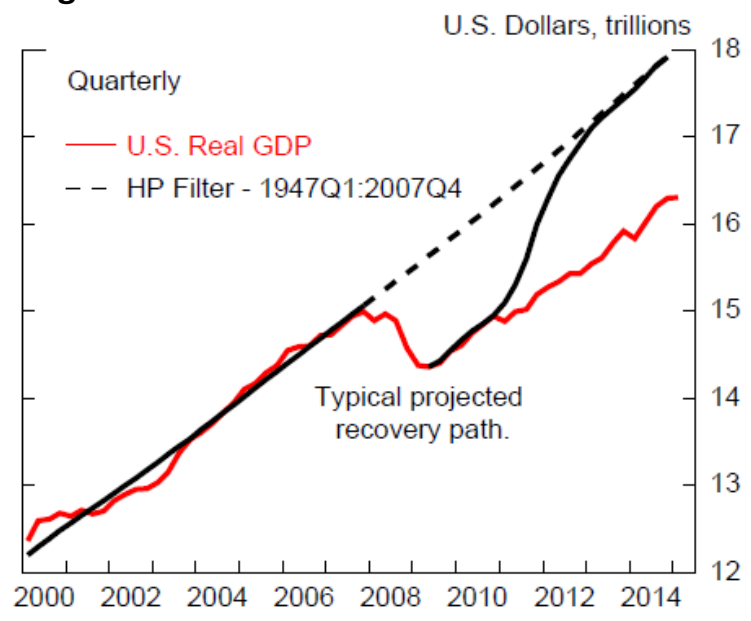

\section{U.K. Real GDP}

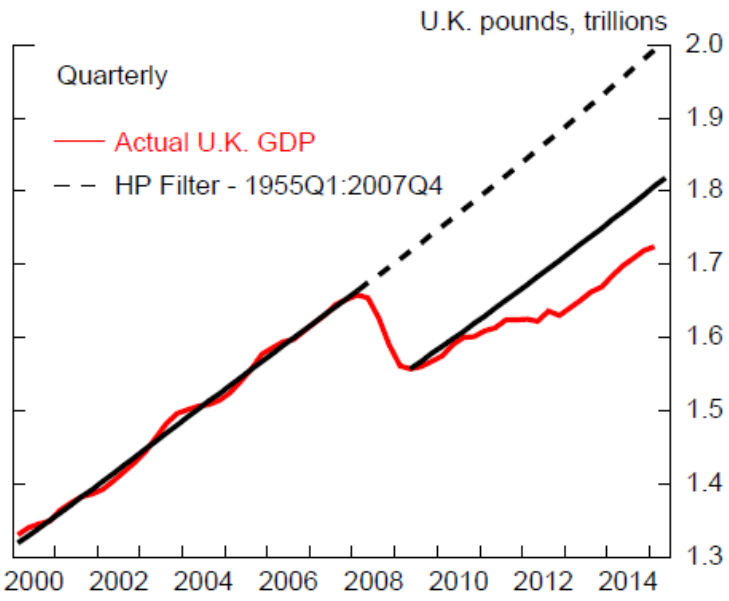

\section{Canadian Real GDP}

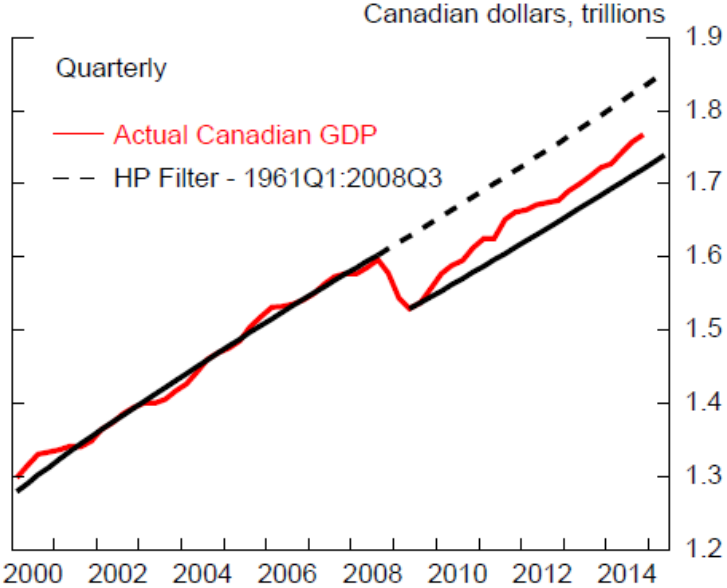


Figure 3. Recoveries in the Advanced Economies

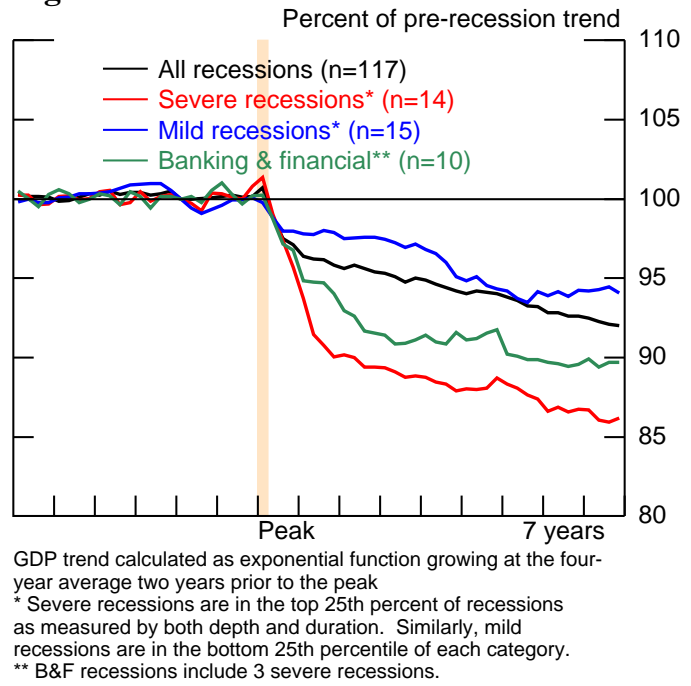

Figure 5. Recoveries in the Advanced Economies

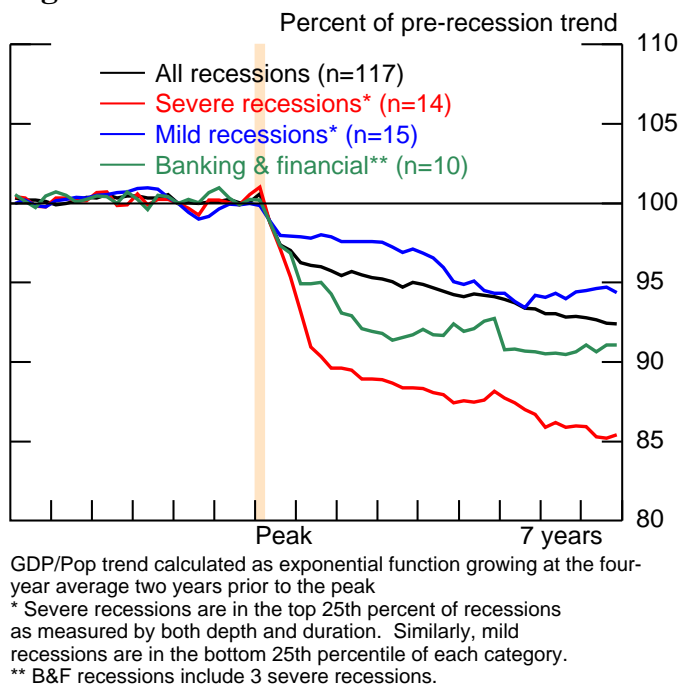

Figure 4. Growth Rates in the Advanced Economies

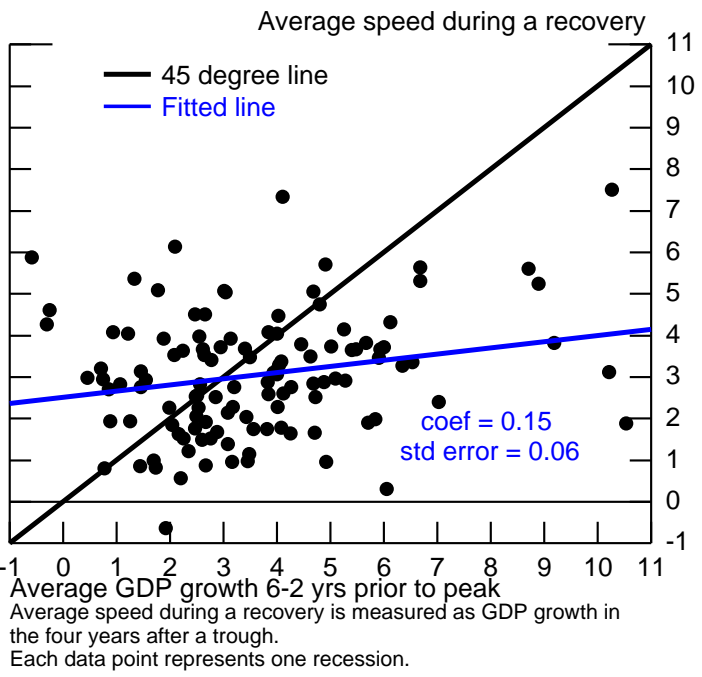

Figure 6. Growth Rates in the Advanced Economies

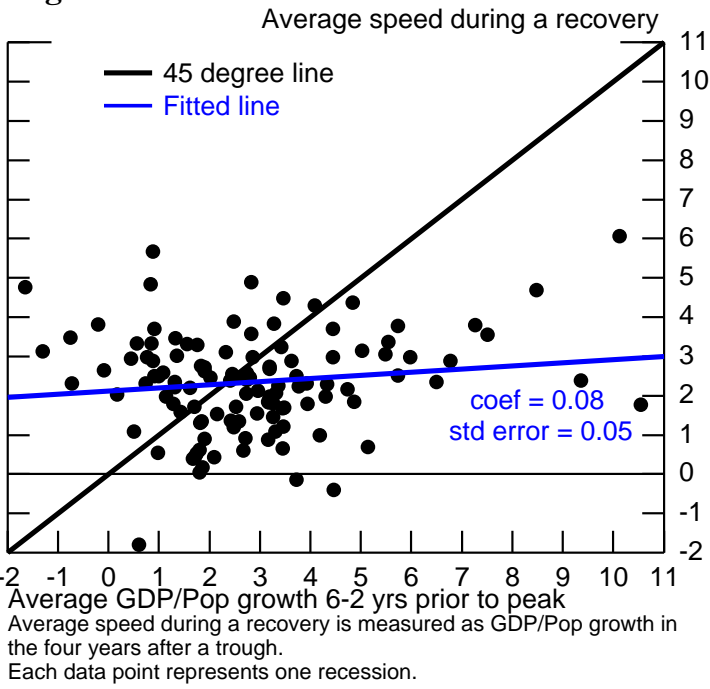




\section{Supply-side Components of GDP for Select Advanced Economies}

Figure 7. GDP

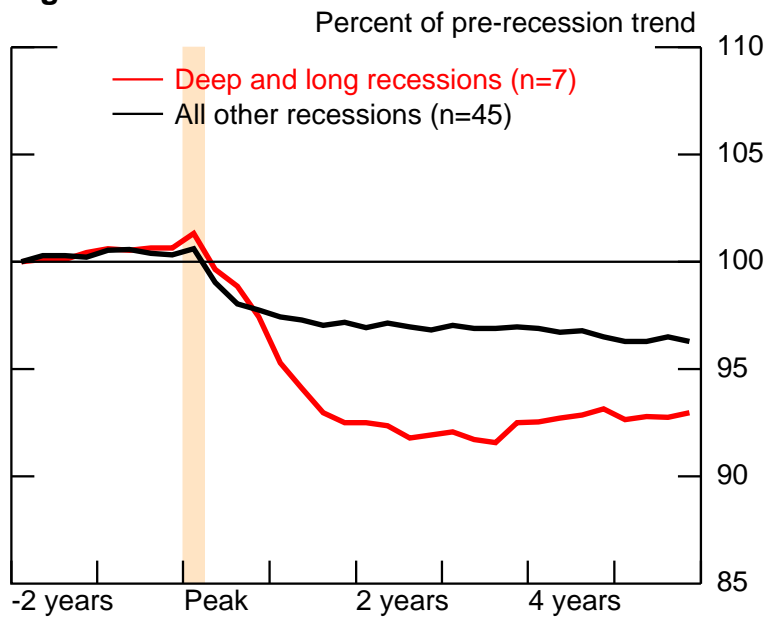

Figure 9. Output per Hour

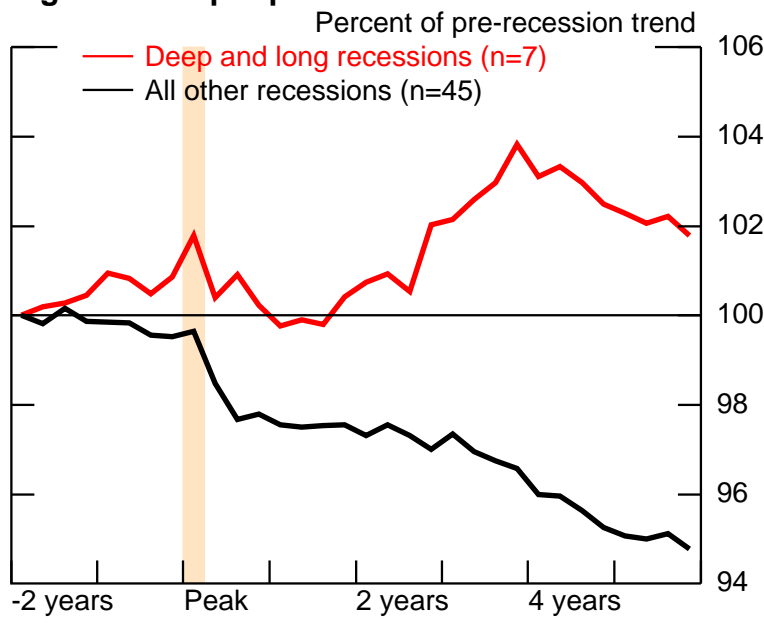

Figure 11. Employment Rate

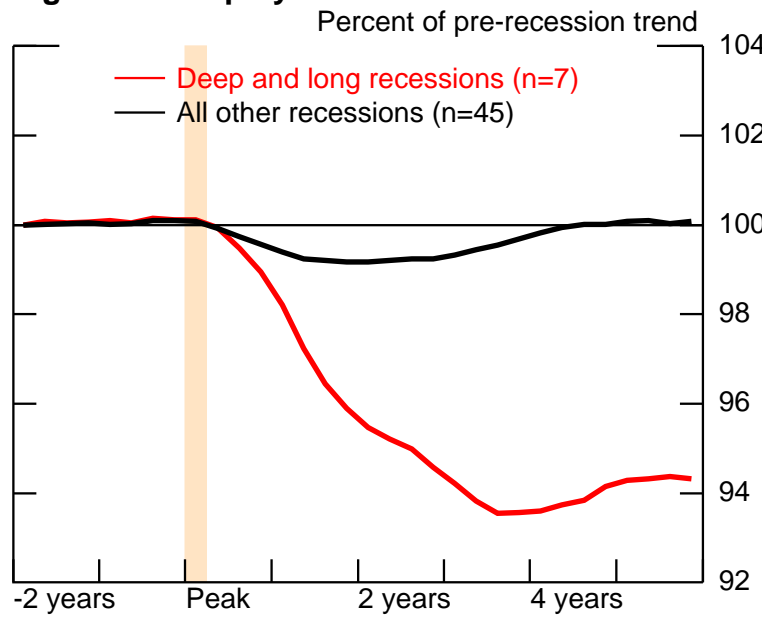

Figure 8. Total Hours

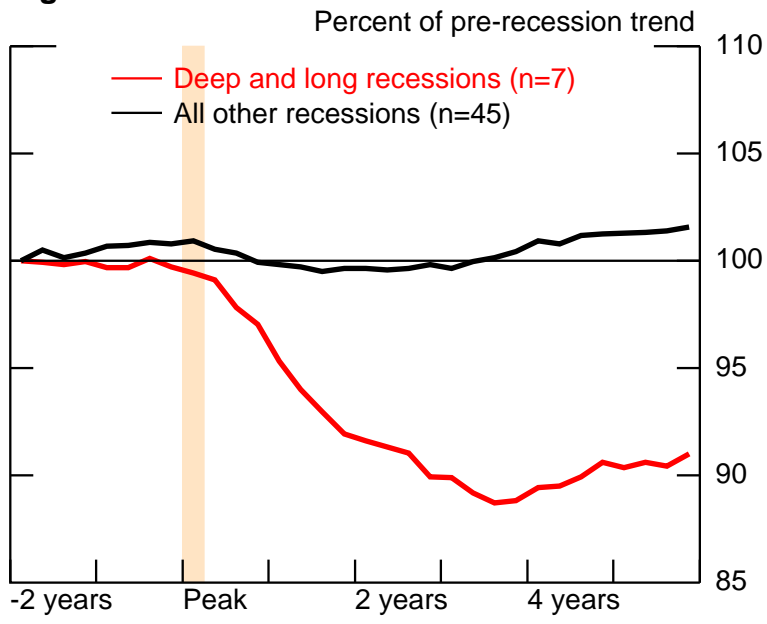

Figure 10. Labor Force Participation

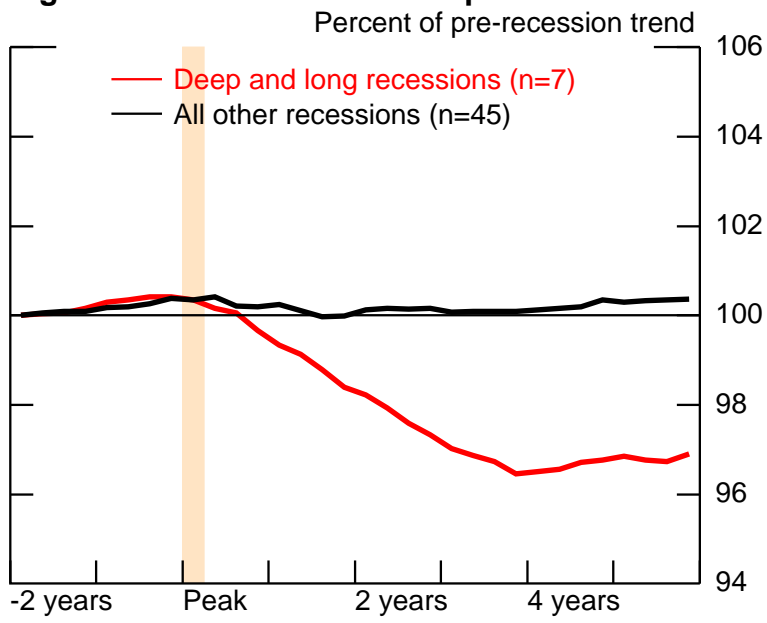

Figure 12. Average Weekly Hours

Percent of pre-recession trend

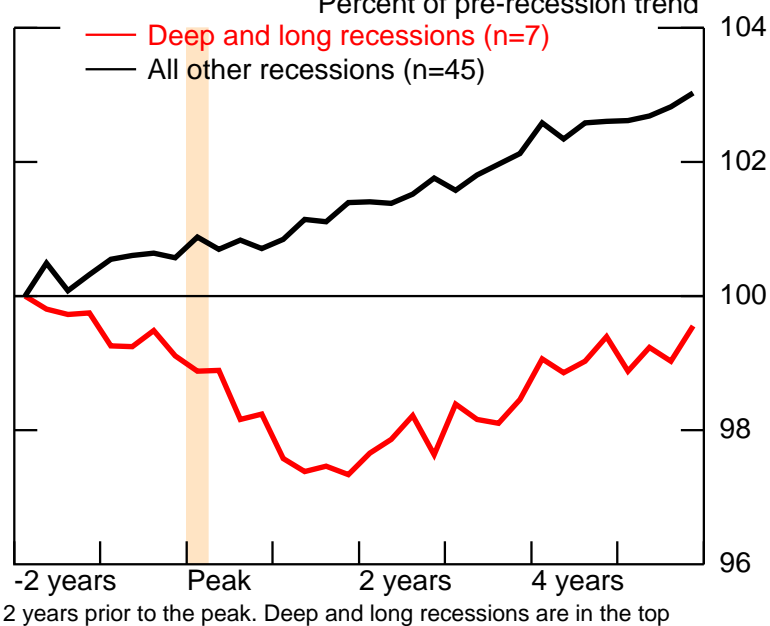

Solid lines are means. Trend is exponential function growing at the 4-year average 2 years prior to the peak. Deep and long recessions are in the top 25th percent of recessions measured by depth and duration. Data are from Raffo and Ohanian (2014 update). 


\section{Demand-side Components of GDP for Select Advanced Economies}

Figure 13. GDP

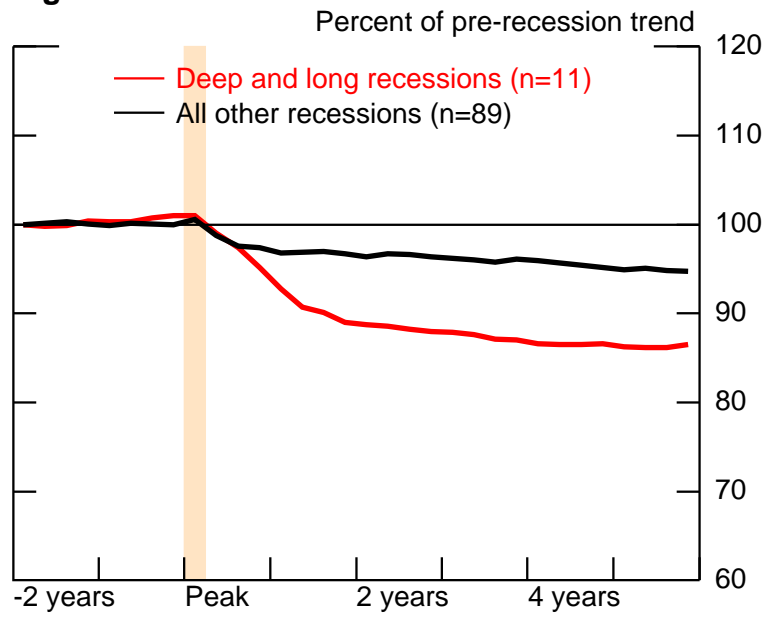

Figure 15. Investment

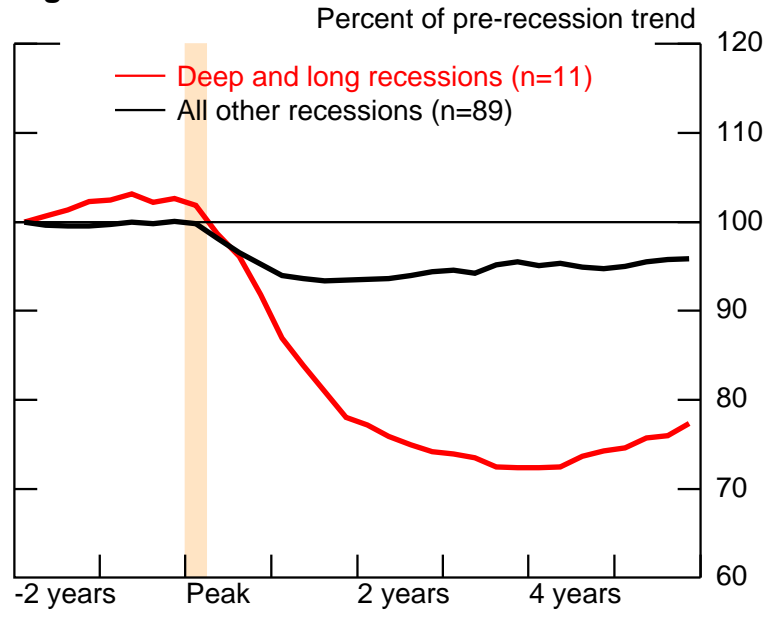

Figure 17. Exports

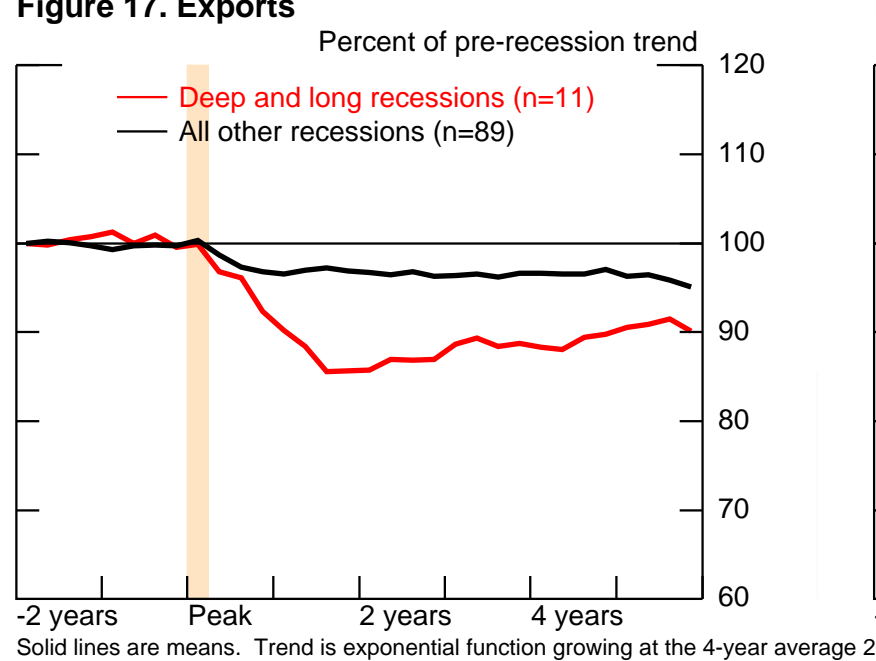

Figure 14. Consumption

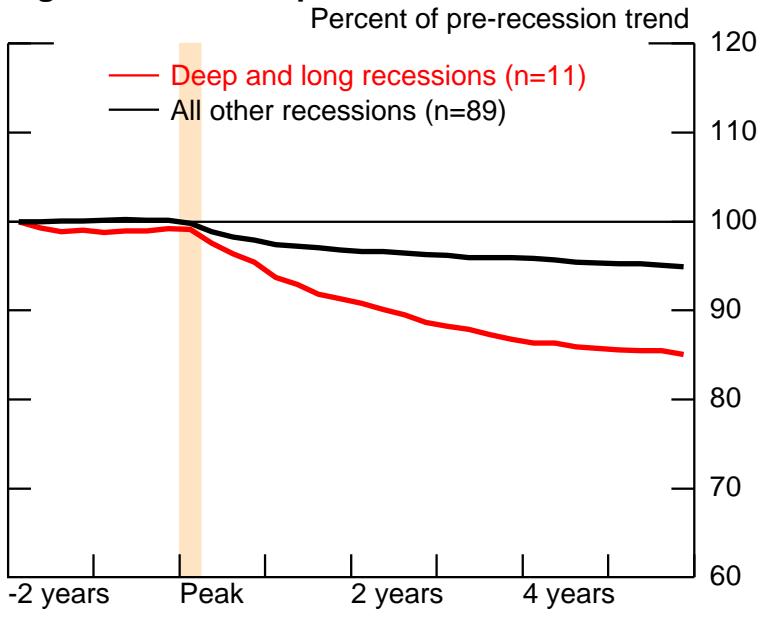

Figure 16. Government

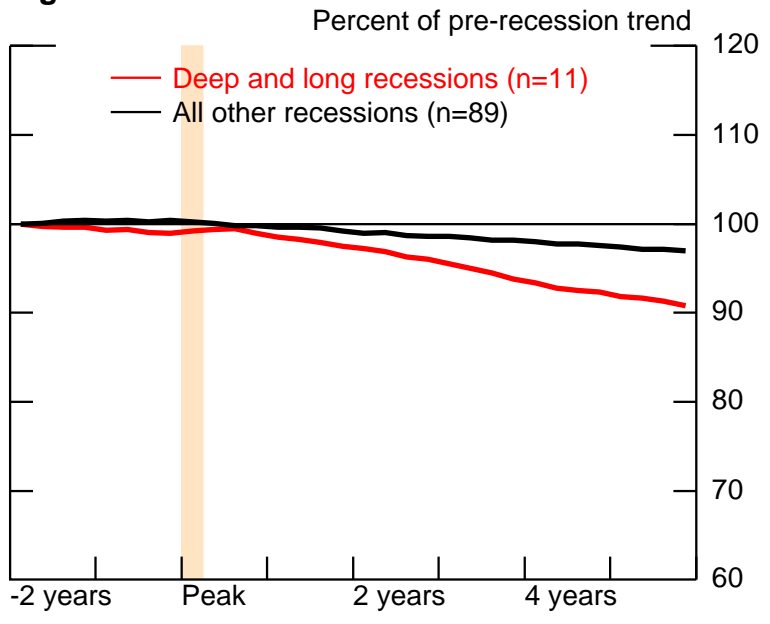

Figure 18. Imports

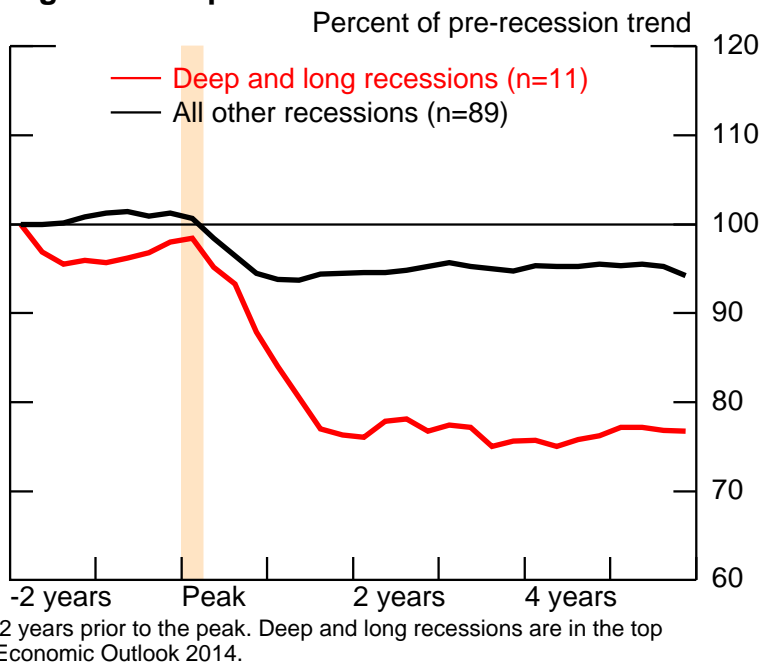


Figure 19.

Real U.S. GDP and HP Filtered GDP Before and After 2009 Recession

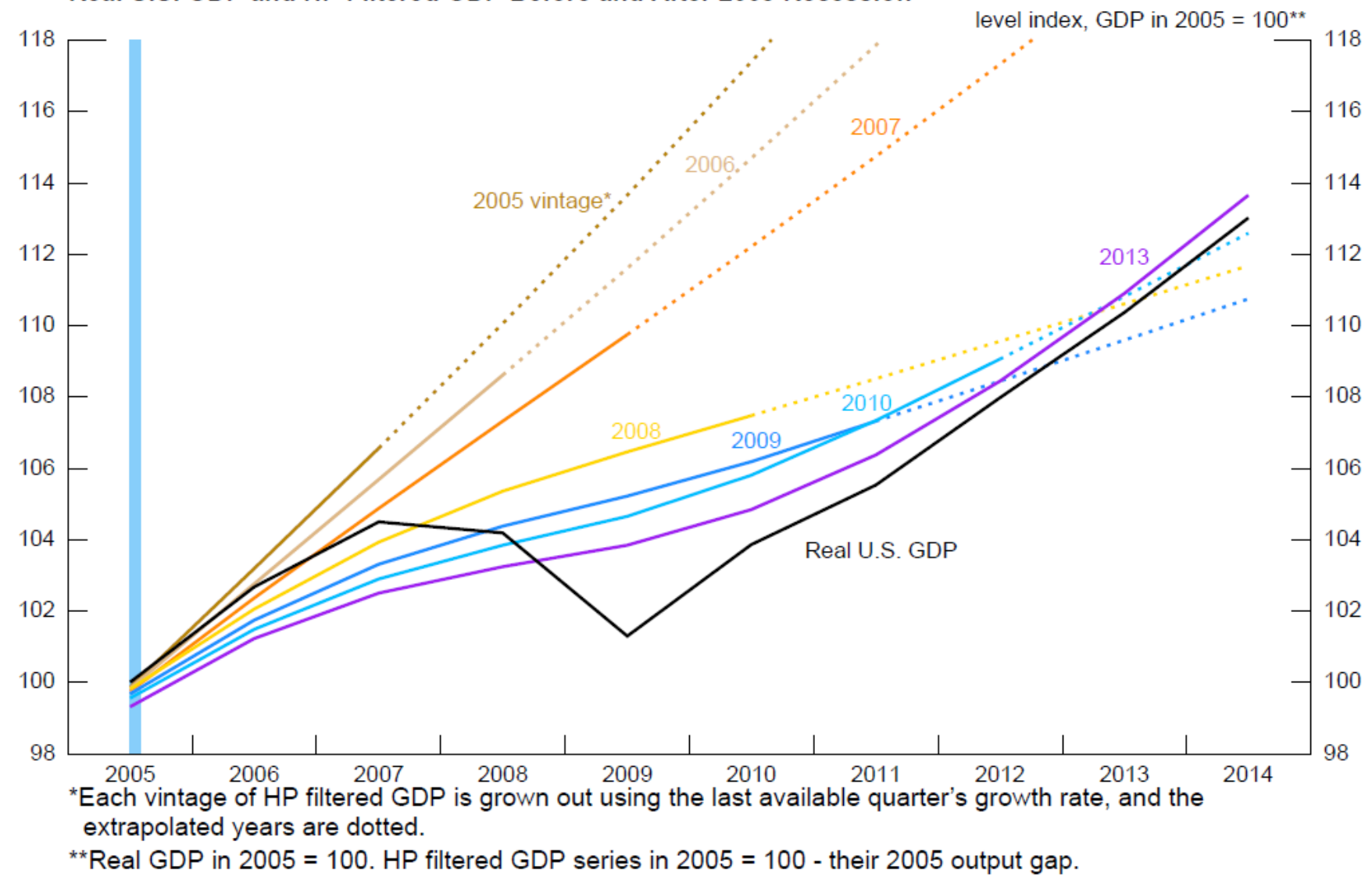


Fig 20. Potential GDP Forecasts (various vintages)

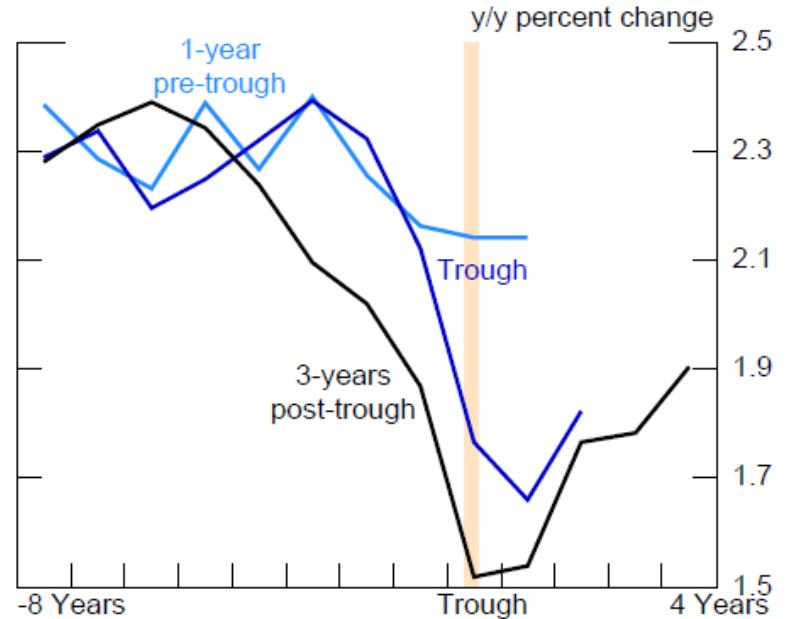

Source: OECD Economic Outlook. Data are for 23 countries covering 64 recessions from 1989-2010. Lines represent the median growth rates,

forecast and history, of each country/recession pair for the period closest to the pre-recssion peak, recession trough, and 2 years past-trough.
Fig 22. Inflation Forecasts (various vintages)

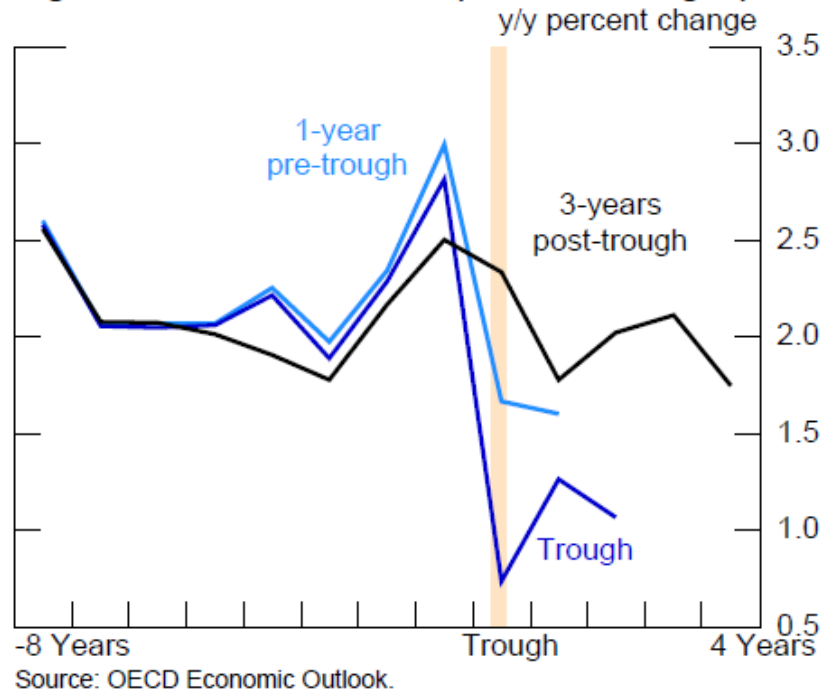

Fig 21. Output Gap Forecasts (various vintages)

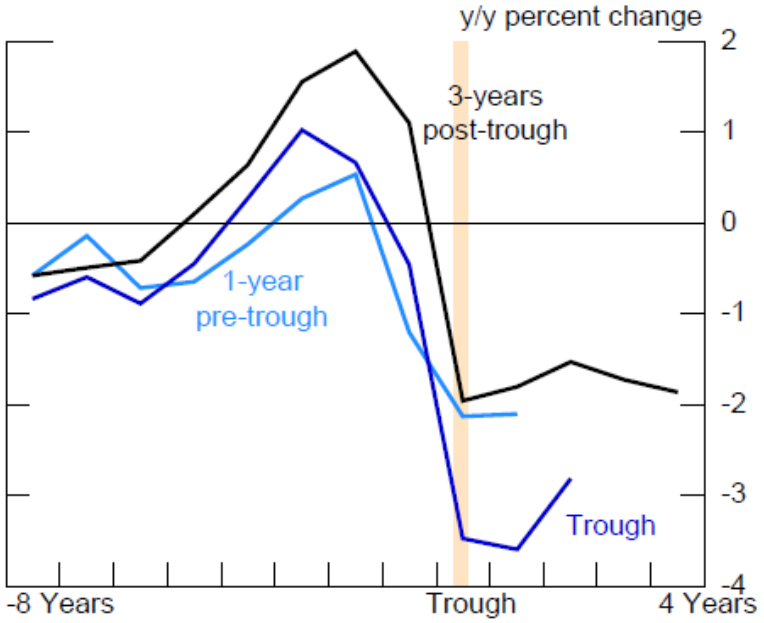

Fig 23. Inflation During Recessions in AEs

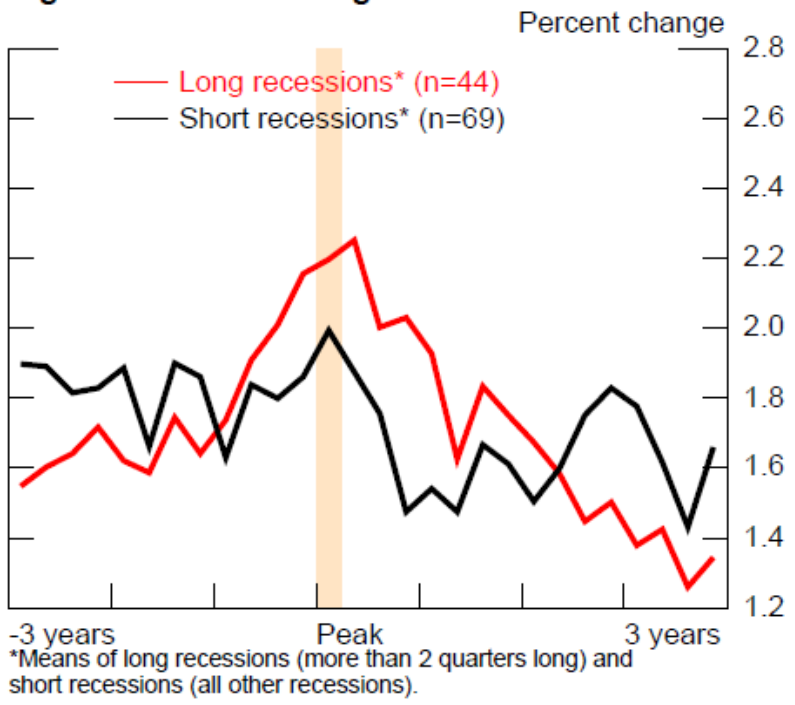

Figure 24. Inflation

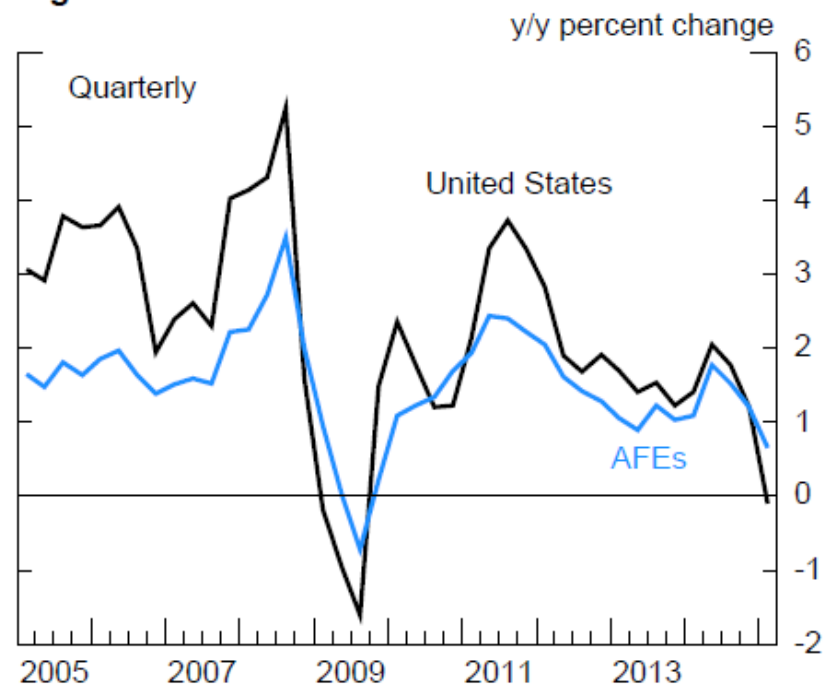


Appendix A. Data by Episode

Duration measured in quarters, Depth as percentage of GDP.

\begin{tabular}{|c|c|c|c|c|c|c|}
\hline Country & Peak & Trough & Duration & Depth & $\begin{array}{c}\text { IMF Banking \& } \\
\text { Financial }\end{array}$ & $\begin{array}{l}\text { Mild or Severe } \\
\text { (non-GFC)* }\end{array}$ \\
\hline Australia & 1971Q3 & 1972Q1 & $2^{-}$ & 1.54 & & \\
\hline Australia & 1975Q2 & 1975Q4 & $2^{-}$ & 2.58 & & \\
\hline Australia & 1977Q2 & 1977Q4 & $2^{-}$ & $0.74^{-}$ & & Mild \\
\hline Australia & 1981Q3 & 1983Q2 & $7^{+}$ & $3.79^{+}$ & & Severe \\
\hline Australia & $1990 \mathrm{Q} 2$ & 1991Q2 & 4 & 1.55 & & \\
\hline Austria & 1974Q3 & 1975Q2 & 3 & 2.14 & & \\
\hline Austria & 1980Q1 & 1981Q1 & 4 & 1.18 & & \\
\hline Austria & 1982Q2 & $1982 Q 4$ & $2^{-}$ & $0.19^{-}$ & & Mild \\
\hline Austria & 1983Q4 & 1984Q2 & $2^{-}$ & 2.17 & & \\
\hline Austria & 1987Q4 & 1988Q3 & 3 & 1.41 & & \\
\hline Austria & $1992 \mathrm{Q} 2$ & 1993Q1 & 3 & $0.59^{-}$ & & \\
\hline Austria & $2000 \mathrm{Q} 4$ & 2001Q3 & 3 & $0.68^{-}$ & & \\
\hline Austria & 2008Q1 & 2009Q2 & $5^{+}$ & $5.74^{+}$ & Banking & \\
\hline Austria & 2012Q1 & 2013Q1 & 4 & $0.46^{-}$ & & \\
\hline Belgium & $1974 Q 2$ & 1975Q2 & 4 & 2.75 & & \\
\hline Belgium & 1976Q4 & 1977Q2 & $2^{-}$ & $0.79^{-}$ & & Mild \\
\hline Belgium & 1979Q4 & 1980Q4 & 4 & 2.03 & & \\
\hline Belgium & 1982Q3 & 1983Q1 & $2^{-}$ & $0.71^{-}$ & & Mild \\
\hline Belgium & 1992Q1 & 1993Q1 & 4 & 2.98 & & \\
\hline Belgium & 2001Q1 & 2001Q4 & 3 & $0.38^{-}$ & & \\
\hline Belgium & 2008Q2 & 2009Q1 & 3 & $4.23^{+}$ & Banking & \\
\hline Canada & 1981Q2 & 1982Q4 & $6^{+}$ & $5.09^{+}$ & & Severe \\
\hline Canada & 1990Q1 & 1991Q1 & 4 & $3.38^{+}$ & & \\
\hline Canada & 2008Q3 & 2009Q2 & 3 & $4.19^{+}$ & & \\
\hline Denmark & 1973Q3 & 1975Q2 & $7^{+}$ & $4.23^{+}$ & & Severe \\
\hline Denmark & 1976Q4 & 1977Q2 & $2^{-}$ & $0.32^{-}$ & & Mild \\
\hline Denmark & 1979Q4 & 1981Q2 & $6^{+}$ & 3.33 & & \\
\hline Denmark & 1986Q4 & 1987Q2 & $2^{-}$ & $0.62^{-}$ & & Mild \\
\hline Denmark & 1988Q4 & 1989Q2 & $2^{-}$ & $0.17^{-}$ & & Mild \\
\hline Denmark & 1990Q2 & 1990Q4 & $2^{-}$ & 2.19 & & \\
\hline Denmark & $1992 \mathrm{Q} 3$ & 1993Q2 & 3 & 2.06 & & \\
\hline Denmark & 1997Q2 & 1997Q4 & $2^{-}$ & $0.3^{-}$ & & Mild \\
\hline Denmark & 2007Q4 & 2009Q2 & $6^{+}$ & $7.44^{+}$ & Banking & \\
\hline Denmark & 2011Q2 & 2013Q2 & $8^{+}$ & 2.55 & & \\
\hline
\end{tabular}

*Severe recessions are non-GFC recessions in the top 25 th percentile of recessions as measured by both depth and duration (length $>4 \&$ drop $>3.33$ ) and similarly mild recessions are in the bottom 25 th percentile of both categories (length=2 \& drop<0.82) In the depth and duration colvmns, +or - indicate if they are above or below the cutoffs discussed above. 
Appendix A. Data by Episode

Duration measured in quarters, Depth as percentage of GDP.

\begin{tabular}{|c|c|c|c|c|c|c|}
\hline Country & Peak & Trough & Duration & Depth & $\begin{array}{c}\text { IMF Banking \& } \\
\text { Financial }\end{array}$ & $\begin{array}{l}\text { Mild or Severe } \\
\text { (non-GFC)** }\end{array}$ \\
\hline Finland & 1971Q2 & 1971Q4 & $2^{-}$ & $0.47^{-}$ & & Mild \\
\hline Finland & 1975Q1 & $1975 \mathrm{Q} 4$ & 3 & 2.57 & & \\
\hline Finland & 1976Q4 & 1977Q2 & $2^{-}$ & 0.98 & & \\
\hline Finland & $1980 \mathrm{Q} 3$ & 1981Q1 & $2^{-}$ & 2.9 & & \\
\hline Finland & $1989 Q 4$ & 1993Q1 & $13^{+}$ & $12.6^{+}$ & Banking, Currency & Severe \\
\hline Finland & $2007 Q 4$ & $2009 \mathrm{Q} 2$ & $6^{+}$ & $10.4^{+}$ & & \\
\hline Finland & 2012Q1 & 2013Q1 & 4 & 2.73 & & \\
\hline France & $1974 Q 3$ & 1975Q1 & $2^{-}$ & 2.09 & & \\
\hline France & $1980 Q 1$ & $1980 Q 4$ & 3 & $0.7^{-}$ & & \\
\hline France & $1990 \mathrm{Q} 3$ & 1991Q1 & $2^{-}$ & $0.12^{-}$ & & Mild \\
\hline France & $1992 \mathrm{Q} 1$ & 1993Q1 & 4 & 1.1 & & \\
\hline France & $2008 Q 1$ & $2009 \mathrm{Q} 2$ & $5^{+}$ & $3.98^{+}$ & Banking & \\
\hline France & $2012 Q 1$ & $2012 Q 4$ & 3 & $0.26^{-}$ & & \\
\hline Germany & 1974Q1 & 1975Q1 & 4 & $3.62^{+}$ & & \\
\hline Germany & 1977Q1 & 1977Q3 & $2^{-}$ & $0.39^{-}$ & & Mild \\
\hline Germany & 1980Q1 & $1980 Q 4$ & 3 & 2.28 & & \\
\hline Germany & 1985Q3 & 1986Q1 & $2^{-}$ & 1.57 & & \\
\hline Germany & $1992 Q 1$ & 1993Q1 & 4 & 2.03 & & \\
\hline Germany & $1995 \mathrm{Q} 3$ & 1996Q1 & $2^{-}$ & 1.02 & & \\
\hline Germany & $2002 Q 3$ & $2003 \mathrm{Q} 1$ & $2^{-}$ & 1.42 & & \\
\hline Germany & $2004 Q 2$ & $2005 \mathrm{Q} 1$ & 3 & 0.29 & & \\
\hline Germany & $2008 Q 1$ & $2009 \mathrm{Q} 1$ & 4 & $6.92^{+}$ & Banking & \\
\hline Germany & $2012 Q 3$ & 2013Q1 & $2^{-}$ & 0.82 & & \\
\hline Greece & 1973Q4 & $1974 Q 3$ & 3 & $13.22^{+}$ & & \\
\hline Greece & $1980 \mathrm{Q} 1$ & $1983 Q 2$ & $13^{+}$ & $9.27^{+}$ & Currency & Severe \\
\hline Greece & $1985 Q 4$ & 1987Q2 & $6^{+}$ & $8.63^{+}$ & & Severe \\
\hline Greece & 1990Q1 & $1990 \mathrm{Q} 3$ & $2^{-}$ & $9.44^{+}$ & & \\
\hline Greece & $1992 Q 1$ & 1993Q1 & 4 & $4.69^{+}$ & & \\
\hline Greece & $1994 Q 3$ & 1995Q1 & $2^{-}$ & 1.17 & & \\
\hline Greece & $2004 Q 3$ & $2005 \mathrm{Q} 1$ & $2^{-}$ & 0.85 & & \\
\hline Greece & $2007 \mathrm{Q} 2$ & $2013 Q 4$ & $26^{+}$ & $27.44^{+}$ & Banking, Debt & \\
\hline Iceland & $1982 Q 2$ & $1983 Q 2$ & 4 & 2.78 & Currency & \\
\hline Iceland & 1987Q4 & 1988Q4 & 4 & 1.51 & & \\
\hline Iceland & 1991Q1 & $1992 Q 4$ & $7^{+}$ & $4.71^{+}$ & & Severe \\
\hline Iceland & $1994 Q 3$ & 1995Q1 & $2^{-}$ & $0.75^{-}$ & & Mild \\
\hline Iceland & $2000 \mathrm{Q} 3$ & 2001Q1 & $2^{-}$ & 2.33 & & \\
\hline Iceland & $2007 Q 4$ & $2010 \mathrm{Q} 2$ & $10^{+}$ & $11.73^{+}$ & Banking, Currency & \\
\hline Ireland & $1982 Q 3$ & 1983Q2 & 3 & 1.02 & & \\
\hline Ireland & 1985Q3 & 1986Q2 & 3 & 1.28 & & \\
\hline Ireland & $2007 \mathrm{Q}$ & $2009 \mathrm{Q} 4$ & $8^{+}$ & $12.11^{+}$ & Banking & \\
\hline Ireland & 2011Q4 & $2012 Q 2$ & $2^{-}$ & 2.53 & & \\
\hline
\end{tabular}

- Severe recessions are non-GFC recessions in the top 25 th percentile of recessions as measured by both depth and duration (length $>4 \&$ drop $>3.33$ ) and similarly mild recessions are in the bottom 25th percentile of both categories (length $=28 d r o p<0.82$ ) In the depth and duration columns, + or - indicate if they are above or below the cutoffs discussed above. 
Appendix A. Data by Episode

Duration measured in quarters, Depth as percentage of GDP.

\begin{tabular}{|c|c|c|c|c|c|c|}
\hline Country & Peak & Trough & Duration & Depth & $\begin{array}{c}\text { IMF Banking \& } \\
\text { Financial }\end{array}$ & $\begin{array}{l}\text { Mild or Severe } \\
\text { (non-GFC) }\end{array}$ \\
\hline Italy & 1974 Q3 & $1975 \mathrm{Q} 2$ & 3 & $3.84^{+}$ & & \\
\hline Italy & 1977Q1 & 1977Q3 & 2 & 1.49 & & \\
\hline Italy & $1982 \mathrm{Q} 1$ & $1982 Q 4$ & 3 & 1.41 & Currency & \\
\hline Italy & 1992Q1 & $1993 \mathrm{Q} 3$ & $6^{+}$ & 2.24 & & \\
\hline Italy & 1996Q1 & $1996 Q 4$ & 3 & $0.44^{-}$ & & \\
\hline Italy & 1997Q4 & $1998 \mathrm{Q} 4$ & 4 & $0.35^{-}$ & & \\
\hline Italy & 2001Q1 & $2001 Q 4$ & 3 & $0.69^{-}$ & & \\
\hline Italy & $2002 Q 4$ & $2003 \mathrm{Q} 2$ & $2^{-}$ & $0.43^{-}$ & & Mild \\
\hline Italy & $2008 \mathrm{Q} 1$ & $2009 \mathrm{Q} 2$ & $5^{+}$ & $7.59^{+}$ & Banking & \\
\hline Japan & 1993Q1 & 1993Q3 & $2^{-}$ & 1.35 & & \\
\hline Japan & 1997Q1 & 1998Q2 & $5^{+}$ & 3.03 & Banking & \\
\hline Japan & 2001Q1 & $2002 Q 1$ & 4 & 1.63 & & \\
\hline Japan & 2008Q1 & $2009 \mathrm{Q} 1$ & 4 & $9.21^{+}$ & & \\
\hline Japan & $2010 Q^{3}$ & $2011 Q 2$ & 3 & 3 & & \\
\hline Luxembourg & $1974 Q 2$ & $1975 \mathrm{Q} 3$ & $5^{+}$ & $8.34^{+}$ & & Severe \\
\hline Luxembourg & $1980 \mathrm{Q} 2$ & 1981Q2 & 4 & $0.74^{-}$ & & \\
\hline Luxembourg & $2002 \mathrm{Q} 2$ & 2003Q1 & 3 & 3.13 & & \\
\hline Luxembourg & $2008 \mathrm{Q} 1$ & $2009 \mathrm{Q} 2$ & $5^{+}$ & $8.95^{+}$ & Banking & \\
\hline Netherlands & 1973Q1 & $1973 Q 3$ & $2^{-}$ & 1.04 & & \\
\hline Netherlands & 1974 Q3 & $1975 \mathrm{Q} 1$ & $2^{-}$ & 3.31 & & \\
\hline Netherlands & 1979 Q4 & $1980 \mathrm{Q} 3$ & 3 & 2.57 & & \\
\hline Netherlands & $1982 Q 1$ & $1982 Q 4$ & 3 & $3.42^{+}$ & & \\
\hline Netherlands & $2008 \mathrm{Q} 1$ & $2009 \mathrm{Q} 2$ & $5^{+}$ & $4.15^{+}$ & Banking & \\
\hline Netherlands & 2011Q1 & $2013 \mathrm{Q} 2$ & $9^{+}$ & 3.05 & & \\
\hline Norway & 1973Q3 & $1975 \mathrm{Q} 1$ & $6^{+}$ & 2.88 & & \\
\hline Norway & $1977 Q 4$ & $1979 \mathrm{Q} 1$ & $5^{+}$ & 2.78 & & \\
\hline Norway & $1980 \mathrm{Q} 1$ & $1980 \mathrm{Q} 3$ & $2^{-}$ & $3.72^{+}$ & & \\
\hline Norway & $1987 Q 2$ & $1988 Q 2$ & 4 & 2.46 & & \\
\hline Norway & 1992Q3 & 1993Q1 & $2^{-}$ & 1.06 & Banking & \\
\hline Norway & $2002 Q 2$ & $2003 Q 2$ & 4 & $0.81^{-}$ & & \\
\hline Norway & $2007 \mathrm{Q} 4$ & $2010 \mathrm{Q} 3$ & $11^{+}$ & $4.28^{+}$ & & \\
\hline New Zealand & 1971Q3 & $1972 Q 1$ & $2^{-}$ & $6.46^{+}$ & & \\
\hline New Zealand & 1973Q1 & 1973Q3 & $2^{-}$ & $7.67^{+}$ & & \\
\hline New Zealand & $1974 Q 3$ & $1975 \mathrm{Q} 2$ & 3 & $10.02^{+}$ & & \\
\hline New Zealand & $1976 \mathrm{Q} 4$ & 1978Q1 & $5^{+}$ & $14.54^{+}$ & & Severe \\
\hline New Zealand & $1982 Q 3$ & $1983 \mathrm{Q} 1$ & $2^{-}$ & $5.22^{+}$ & & \\
\hline New Zealand & $1985 \mathrm{Q} 1$ & $1986 \mathrm{Q} 1$ & 4 & $5.85^{+}$ & Currency & \\
\hline New Zealand & $1990 \mathrm{Q} 4$ & 1991Q2 & $2^{-}$ & $4.2^{+}$ & & \\
\hline New Zealand & 1997Q3 & 1998Q2 & 3 & 2.29 & & \\
\hline New Zealand & $2000 \mathrm{Q} 1$ & $2001 \mathrm{Q} 1$ & 4 & 0.95 & & \\
\hline New Zealand & $2007 Q 4$ & $2009 \mathrm{Q} 1$ & $5^{+}$ & 3.32 & & \\
\hline New Zealand & $2010 \mathrm{Q} 2$ & $2010 Q 4$ & $2^{-}$ & 2.25 & & \\
\hline
\end{tabular}

'Severe recessions are non-GFC recessions in the top 25 th percentile of recessions as measured by both depth and duration (length $>4 \&$ drop $>3.33$ ) and similarly mild recessions are in the bottom 25 th percentile of both categories (length $=2 \&$ drop $<0.82$ ) In the depth and duration columns, + or - indicate if they are above or below the cutoffs discussed above. 
Appendix A. Data by Episode

Duration measured in quarters, Depth as percentage of GDP.

\begin{tabular}{|c|c|c|c|c|c|c|}
\hline Country & Peak & Trough & Duration & Depth & $\begin{array}{l}\text { IMF Banking \& } \\
\text { Financial }\end{array}$ & $\begin{array}{l}\text { Mild or Severe } \\
\text { (non-GFC)* }\end{array}$ \\
\hline Portugal & 1974Q1 & 1975Q2 & $5^{+}$ & $6.03^{+}$ & & Severe \\
\hline Portugal & $1982 Q 4$ & $1984 Q 2$ & $6^{+}$ & 2.7 & Currency & \\
\hline Portugal & 1992Q2 & 1993Q3 & $5^{+}$ & 2.56 & & \\
\hline Portugal & $2002 \mathrm{Q} 1$ & 2003Q2 & $5^{+}$ & 2.41 & & \\
\hline Portugal & 2004Q2 & 2004Q4 & $2^{-}$ & $0.3^{-}$ & & Mild \\
\hline Portugal & 2008Q1 & $2009 \mathrm{Q} 1$ & 4 & $4.3^{+}$ & Banking & \\
\hline Portugal & 2010 Q3 & $2012 Q 4$ & $9^{+}$ & $7.3^{+}$ & & \\
\hline Sweden & 1973Q1 & 1973Q3 & $2^{-}$ & 1.93 & & \\
\hline Sweden & $1976 \mathrm{Q} 4$ & 1977Q2 & $2^{-}$ & 3.31 & & \\
\hline Sweden & $1982 Q 3$ & 1983Q1 & $2^{-}$ & 1.23 & & \\
\hline Sweden & $1990 \mathrm{Q} 2$ & $1992 \mathrm{Q} 4$ & $10^{+}$ & $5.81^{+}$ & Banking & Severe \\
\hline Sweden & $2007 \mathrm{Q} 4$ & $2009 \mathrm{Q} 3$ & $7^{+}$ & $7.24^{+}$ & Banking & \\
\hline Sweden & 2011Q3 & 2012Q4 & $5^{+}$ & 1.06 & & \\
\hline Spain & 1974Q4 & 1975Q2 & $2^{-}$ & $0.58^{-}$ & & Mild \\
\hline Spain & 1978Q2 & 1979Q1 & 3 & $0.43^{-}$ & Banking & \\
\hline Spain & 1980Q1 & 1981Q2 & $5^{+}$ & $0.27^{-}$ & & \\
\hline Spain & 1992Q1 & 1993Q2 & $5^{+}$ & 1.83 & & \\
\hline Spain & 2008Q2 & 2013Q2 & $20^{+}$ & $8.25^{+}$ & Banking & \\
\hline Switzerland & 1974Q2 & 1976Q1 & $7^{+}$ & $13.1^{+}$ & & Severe \\
\hline Switzerland & 1981Q4 & $1982 Q 4$ & 4 & $3.92^{+}$ & & \\
\hline Switzerland & $1990 \mathrm{Q} 2$ & $1992 \mathrm{Q} 4$ & $10^{+}$ & 2.28 & & \\
\hline Switzerland & 1995Q4 & 1996Q3 & 3 & $0.39^{-}$ & & \\
\hline Switzerland & $2002 \mathrm{Q} 2$ & 2003Q2 & 4 & 0.89 & & \\
\hline Switzerland & 2008Q3 & 2009Q2 & 3 & $3.37^{+}$ & Banking & \\
\hline United Kingdom & 1973Q2 & 1975Q3 & $9^{+}$ & $5.51^{+}$ & & Severe \\
\hline United Kingdom & 1979Q2 & 1981Q1 & $7^{+}$ & $5.57^{+}$ & & Severe \\
\hline United Kingdom & 1990Q2 & 1991Q3 & $5^{+}$ & 2.2 & & \\
\hline United Kingdom & $2008 Q 1$ & $2009 \mathrm{Q} 2$ & $5^{+}$ & $6.04^{+}$ & Banking & \\
\hline United States & 1969 Q3 & 1970Q1 & $2^{-}$ & $0.61^{-}$ & & Mild \\
\hline United States & 1973 Q4 & 1975Q1 & $5^{+}$ & 3.11 & & \\
\hline United States & 1980Q1 & $1980 \mathrm{Q} 3$ & $2^{-}$ & 2.18 & & \\
\hline United States & 1981Q3 & 1982Q1 & $2^{-}$ & 2.82 & & \\
\hline United States & 1990 Q3 & 1991Q1 & $2^{-}$ & 1.32 & & \\
\hline United States & $2007 \mathrm{Q} 4$ & $2009 \mathrm{Q} 2$ & $6^{+}$ & $4.24^{+}$ & Banking & \\
\hline
\end{tabular}

- Severe recessions are non-GFC recessions in the top 25 th percentile of recessions as measured by both depth and duration (length $>48$ drop $>3.33$ ) and similarly mild recessions are in the bottom 25th percentile of both categories (length $=28$ drop $<0.82$ ) In the depth and duration columns, + or - indicate if they are above or below the cutoffs discussed above. 
Appendix B. Sample countries

\begin{tabular}{lc} 
Country & First Value \\
\hline Australia & $1959 \mathrm{Q} 3$ \\
Austria & $1970 \mathrm{Q} 1$ \\
Belgium & $1970 \mathrm{Q} 1$ \\
Canada & $1961 \mathrm{Q} 1$ \\
Denmark & $1966 \mathrm{Q} 1$ \\
Finland & $1970 \mathrm{Q} 1$ \\
France & $1949 \mathrm{Q} 1$ \\
Germany & $1960 \mathrm{Q} 1$ \\
Greece & $1970 \mathrm{Q} 1$ \\
Iceland & $1960 \mathrm{Q} 1$ \\
Ireland & $1960 \mathrm{Q} 1$ \\
Italy & $1970 \mathrm{Q} 1$ \\
Japan & $1955 \mathrm{q} 2$ \\
Luxembourg & $1960 \mathrm{Q} 1$ \\
Netherlands & $1960 \mathrm{Q} 1$ \\
Norway & $1970 \mathrm{Q} 1$ \\
New Zealand & $1961 \mathrm{Q} 2$ \\
Portugal & $1960 \mathrm{Q} 1$ \\
Sweden & $1970 \mathrm{Q} 1$ \\
Spain & $1970 \mathrm{Q} 1$ \\
Switzerland & $1965 \mathrm{Q} 1$ \\
United Kingdom & $1955 \mathrm{Q} 1$ \\
United States & $1947 \mathrm{Q} 1$
\end{tabular}

